\title{
Technologies Employed in the Treatment of Water Contaminated with Glyphosate: A Review
}

\author{
Patricio J. Espinoza-Montero ${ }^{1, *(\mathbb{D})}$, Carolina Vega-Verduga ${ }^{1}$, Paulina Alulema-Pullupaxi ${ }^{1}$ (D), \\ Lenys Fernández ${ }^{1}$ and Jose L. Paz ${ }^{2}$ (D) \\ 1 Escuela de Ciencias Químicas, Pontificia Universidad Católica del Ecuador, Quito 17-01-2184, Ecuador; \\ cbvegav@gmail.com (C.V.-V.); pauli95.alp@gmail.com (P.A.-P.); lmfernandez@puce.edu.ec (L.F.) \\ 2 Departamento de Física, Escuela Politécnica Nacional, Ladrón de Guevara, Quito 17-12-866, Ecuador; \\ jose.pazr@epn.edu.ec \\ * Correspondence: pespinoza646@puce.edu.ec; Tel.: +593-2299-1700 (ext. 1929)
}

Academic Editor: Derek J. McPhee

Received: 30 September 2020; Accepted: 19 November 2020; Published: 26 November 2020

\begin{abstract}
Glyphosate [ $N$-(phosphonomethyl)-glycine] is a herbicide with several commercial formulations that are used generally in agriculture for the control of various weeds. It is the most used pesticide in the world and comprises multiple constituents (coadjutants, salts, and others) that help to effectively reach the action's mechanism in plants. Due to its extensive and inadequate use, this herbicide has been frequently detected in water, principally in surface and groundwater nearest to agricultural areas. Its presence in the aquatic environment poses chronic and remote hazards to human health and the environment. Therefore, it becomes necessary to develop treatment processes to remediate aquatic environments polluted with glyphosate, its metabolites, and/or coadjutants. This review is focused on conventional and non-conventional water treatment processes developed for water polluted with glyphosate herbicide; it describes the fundamental mechanism of water treatment processes and their applications are summarized. It addressed biological processes (bacterial and fungi degradation), physicochemical processes (adsorption, membrane filtration), advanced oxidation processes-AOPs (photocatalysis, electrochemical oxidation, photo-electrocatalysis, among others) and combined water treatment processes. Finally, the main operating parameters and the effectiveness of treatment processes are analyzed, ending with an analysis of the challenges in this field of research.
\end{abstract}

Keywords: glyphosate; herbicides; commercial formulation; water pollution; water treatment process

\section{Introduction}

In recent years, the global food demand caused by population growth has motivated an intensive use of agrochemicals in agricultural activities. However, this can cause an environmental impact [1, 2]. One of the major worldwide concerns in our society is water pollution caused by pesticides, because of the potential adverse effects of these compounds on ecosystems and human health [3]. A type of pesticides frequently used in the agricultural areas are herbicides, which are used to kill or inhibit the normal growth of undesirable plants (also called pest) in crops [1,4]. Globally, glyphosate-based herbicides are the agrochemical most widely used because of their effectiveness in crops. This commercial herbicide was first marketed by Monsanto as Roundup in 1974 in the United States. Nowadays, it is commercialized by different names depending on the place [5,6]. In Ecuador, it is mostly commercialized by the name of Glifopac.

Glyphosate or [N-(phosphonomethyl)-glycine] has a highly effective foliar action herbicide because of its characteristics: I) It is a systemic herbicide because inhibits the 5-enolpiruvil-shikimato3-phosphate-synthetase enzyme (EPSP), which is indispensable in essential amino acids synthesis for 
plant growth and development. This herbicide causes leaf decomposition and therefore the plant death between 5 to 30 days after application [6-8]; II) Post-emergent herbicide because it is applied to weeds in their first stages of development; III) Non-selective herbicide because it exerts action on all plant material with which it comes into contact [6-8]. This herbicide is commonly used for soil preparation before sowing, control of undesirable plants in crop areas, control of annual perennial special or invasive vegetation during post-harvest activities. In addition, it is used to control aquatic algae although the use of glyphosate herbicides is not approved for applications in the aquatic environment [4,9]. Because of its high solubility $\left(12 \mathrm{~g} \cdot \mathrm{L}^{-1}\right.$ at $\left.25^{\circ} \mathrm{C}\right)$ this herbicide can be easily detected in surface water and groundwater [4]. The surface water and groundwater contamination with glyphosate can occur through multiple routes: surface runoff, direct overspray, drift during herbicide application, improper application practices and disposal of herbicide wastes such as those originating from empty pesticide containers or fumigation equipment $[6,10]$. In this way, significant quantities of glyphosate, its coadjutants, and its degradation metabolites (such as Aminomethylphosphonic acid or AMPA, sarcosine, glycine, among others) reach aquatic environments; where due to its relatively long half-life ( $\mathrm{t}_{1 / 2}$ glyphosate from 7 to 315 days, most commonly 45-60 days and $t_{1 / 2}$ AMPA from 76 to 240 days), it can persistence in water [11,12]. For this reason, there are studies that demonstrate the presence of glyphosate in surface and groundwater $[6,10]$.

Regarding ecotoxicology, once the herbicide (dose) enters the organism, it can have a toxic effect, which can be in the short (acute), medium (sub-lethal) and long term (chronic). Eco-toxicological studies have determined that glyphosate affects several aquatic trophic levels (freshwater/marine environments), being more toxic than the commercial formulations [12,13]. In terms of the risks posed to humans, the International Agency for Research on Cancer (IARC) of the World Health Organization (WHO) has placed the glyphosate herbicide into the 2A Group (probably carcinogenic to humans) and the Food and Agriculture Organization (FAO) reported that glyphosate and its major metabolite, aminomethylphosphonic acid (AMPA), are of potential toxicological concern, mainly as a result of the accumulation of residues in the food chain [14,15]. Based on health and environmental risks, it becomes necessary to develop strategies regarding water polluted with glyphosate, coadjutants, and metabolites. The conventional and non-conventional processes have been proposed as an alternative to treat water polluted with glyphosate [4]. However, physicochemical processes like coagulation, adsorption, and reverse osmosis, among others, are non-destructive and post-treatments of the adsorbent materials or solid wastes are necessary and costly $[15,16]$. On the other hand, biological processes can generate metabolites (e.g., AMPA) with higher toxicity potential if the operational conditions are not controlled [7]. In recent years, advanced oxidation processes (AOPs) have been proposed as an alternative treatment for water polluted with glyphosate [4]. The advantages of these technologies are related to the short residence times (minutes), reaching removal efficiencies higher than $90 \%$, and a better ability to remove recalcitrant compounds (total mineralization).

This review describes the fundamental mechanism and presents some applications of these treatment processes studied for water polluted with glyphosate herbicide. It includes the basic concepts of each technique, operational conditions, and their effectiveness in water treatment. Conventional and non-conventional treatment processes are described. Biological treatment processes such as bacterial and fungi degradation, physicochemical processes-principally adsorption and membrane filtration-AOPs such as Fenton-based processes, UV-based process, and electrochemical oxidation like anodic oxidation and photoelectrocatalysis, and combined water treatment processes are analyzed. Finally, the challenges in this field of research are analyzed.

\section{Water Treatment Processes to Remove Glyphosate from Water}

\subsection{Biologic Treatment Processes}

Glyphosate biodegradation by microorganisms has been described as a safe, cost-effective and reliable means to remove this pollutant from soil and water [17]. Biodegradation occurs by bacterial or fungal species which generally use glyphosate as a source of nitrogen, carbon and 
phosphorous; after that, glyphosate is transformed into new compounds through different degradation pathways [18,19]. Even though glyphosate biodegradation depends on each microorganism metabolism, the degradation pathway involves enzymes able to cleavage of carboxymethylene-nitrogen $(\mathrm{C}-\mathrm{N})$ bond or carbon-phosphorus (C-P) bond in the molecule $[7,20]$. As a result, AMPA, sarcosine, and acetylglyphosate are formed as intermediate metabolites of degradation [7,18-20]. Different studies have reported effective and potential microorganisms for efficient and rapid bioremediation of glyphosate polluted environments. The work reported by Zhan et al. [7] summarizes some glyphosate-degrading strains (fungi and bacteria). Among glyphosate-degrading bacteria and glyphosate-degrading fungi are Achromobacter spp., Agrobacterium radiobacter, Alcaligenes sp. GL, Arthrobacter spp., Bacillus cereus CB4, Ochrobactrum spp., Pseudomonas spp., Aspergillus niger, Aspergillus oryzae A-F02, Penicillium chrysogenum, Trichoderma harzianum, among others.

Glyphosate biodegradation in bacterial species has three transformation pathways (Figure 1). The first pathway is the formation of AMPA and glyoxylate by the action of an enzyme called glyphosate oxidoreductase which cleavage $\mathrm{C}-\mathrm{N}$ bond in the glyphosate molecule $[7,17]$. AMPA mostly serves as a substrate of enzymes that catalyze the cleavage of $\mathrm{C}-\mathrm{P}$ bond producing methylamine and phosphate, or it can be metabolized to phosphonoformaldehyde by transaminase and then catabolized to formaldehyde and phosphate through phosphonatase enzyme. The glyoxylate molecule can be transformed into glycine and formaldehyde, and then used in microbial metabolism [17]. The second pathway is the formation of sarcosine and phosphate by the action of C-P lyase; after that, sarcosine oxidase transforms sarcosine to glycine and formaldehyde which are used for protein biosynthesis and metabolism in bacteria [7]. The third pathway converts glyphosate to acetylglyphosate and it cannot further utilize it as a nutrient source [7]. Among glyphosate-degrading bacteria are Pseudomonas sp., Bacillus cereus, Arthrobacter sp., Ochrobactrum sp., Achromobacter sp., Alcaligensis sp., Flavobacterium sp., Agrobacterium radiobacter sp., and others. Similar to bacteria, fungi species also utilize glyphosate as a source of phosphorus and nitrogen nutrients for their growth, and use analogous enzymes in the degradation pathway [21].

On the contrary, the fungi biodegradation pathway of glyphosate is shorter than the microbial pathway because fewer secondary metabolites are formed [21]. AMPA is the main metabolite, it is transformed to methylamine and then oxidized to formaldehyde through the action of methylamine dehydrogenase; finally, formaldehyde can be assimilated via the ribulose monophosphate cycle [20]. Only a few glyphosate-degrading fungi species have been reported, for example, Trichoderma viridae, Aspergillus niger, Aspergillus Oryzae, Fusarium oxysporum, Trichoderma harzianum, Scopulariopsis sp, Penicillium citrinum. Degradation pathways of glyphosate in fungi and bacterial species are summarized in Figure 1.

Based on the above, several authors have studied biological treatment to remove glyphosate and AMPA from water: Flavobacterium sp. was the first microorganism identified which can metabolize glyphosate, AMPA and sarcosine; it was applied in activated sludge to treat glyphosate-containing wastes at Monsanto Co. wastewater treatment plant [22]. Agrobacterium radiobacter was isolated from a bench-scale sequencing batch reactor degrading a waste stream containing glyphosate, it utilizes glyphosate as a sole source of carbon and energy [23]. Pseudomonas spp. is able to remove higher than $98 \%$ using a biofilm colonized with bacteria in immobilizing bacterial technology columns (IBT) [24]; a biological bed system using a bagasse-based bio-mix reaches $99 \%$ degradation of this herbicide after 6 months of treatment by bacterial action [25]; native bacteria from seawater are able to remove $48 \%$ of the initial concentration of glyphosate tested in batch culture [26]. Pseudomonas sp. and Bacillus sp. together are an effective microbial culture for biodegrading glyphosate in contaminated soils and aquifers [19]; unacclimated activated sludge culture tested in a batch culture showed its potential to biodegrade glyphosate under aerobic conditions and can be a good candidate for treating waters contaminated with high levels of glyphosate [27]. 


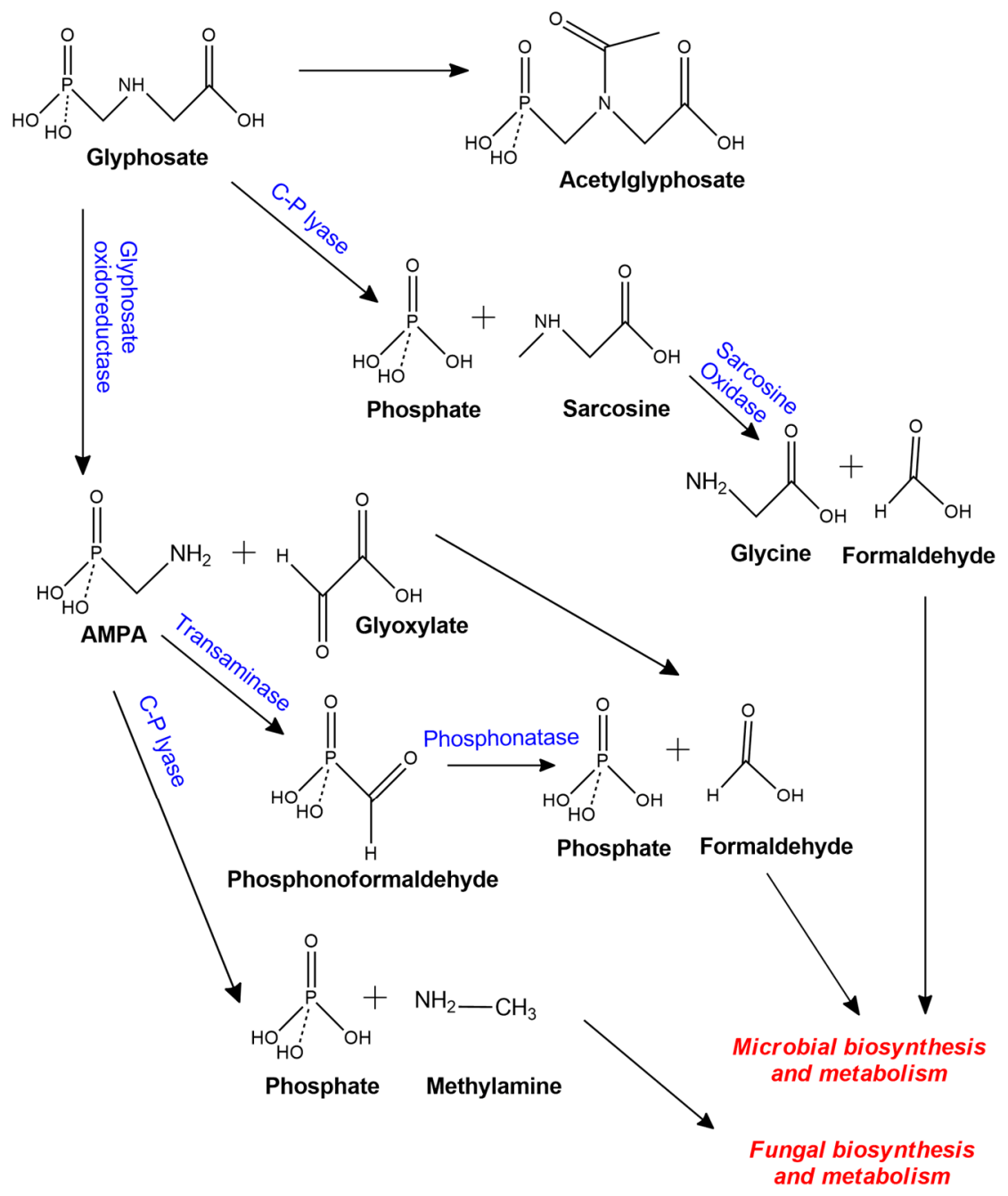

Figure 1. Degradation pathways of glyphosate in fungal and bacterial species $[7,20,21]$.

In the most recent study, Singh et al. [28] evaluated three isolated bacterial strains (Streptomyces sp., Bacillus subtilis, Rhizobium leguminosarum), which were useful in bioremediation of glyphosate polluted environment [28]. Fungal species also have shown glyphosate degradation activity in aqueous media: Fusarium oxysporum strains were capable of biodegrading glyphosate in pure and consortium cultures in a platform shaker and batch bioreactor, they achieved about $41 \%$ degradation efficiency after 5 days of culture [29]. Trichoderma harzianum has been found to have AMPA-degrading activity and achieved $69 \%$ of AMPA degradation after 10 days of incubation [30], a recent study reports the efficiency of Aspergillus oryzae A-F02 isolated from an aeration tank in a pesticide factory, which can transform less than $50 \%$ of glyphosate to AMPA after $72 \mathrm{~h}$ of incubation [20].

As shown above, the biologic treatment appears to be a promising process to remove glyphosate from water. However, this process could present some disadvantages. First, to evaluate the potential of glyphosate-degrading microorganism, it is important to enhance some experimental conditions such as initial $\mathrm{pH}$, incubation temperature, glyphosate concentration, inoculation biomass and incubation time, because all of them are important operational parameters to optimize bioremediation of real water polluted with glyphosate. Second, under controlled conditions, some microorganisms use glyphosate as a sole source of nitrogen or phosphorous, however, in natural ecosystems, their efficiency in glyphosate degradation may drop significantly because, in the majority of cases, the expression of some enzymatic complex (Figure 1) is activated only in response to a specific intracellular deficit and a specific deficiency of nitrogenous or phosphorous, all conditions mentioned could not be typically 
found in glyphosate polluted environments. Remotion of glyphosate from water polluted by biological treatment is summarized in Table 1.

Table 1. Removal of glyphosate from water polluted by biological treatment.

\begin{tabular}{|c|c|c|c|c|}
\hline $\begin{array}{c}\text { Microorganism (Bacteria } \\
\text { and Fungi) }\end{array}$ & Experimental Conditions & $\begin{array}{l}\text { Glyphosate } \\
\text { Concentration } \\
\left(\mathrm{mg} \cdot \mathbf{a . i .} \cdot \mathrm{L}^{-1}\right)\end{array}$ & Removal (\%) & Ref. \\
\hline $\begin{array}{l}\text { Pseudomonas sp.; } \\
\text { Bacillus sp. }\end{array}$ & Batch culture & $50,000-150,000$ & - & [19] \\
\hline Flavobacterium sp. & $\begin{array}{l}\text { Batch culture isolated from } \\
\text { activated sludge }\end{array}$ & - & 25.0 & [22] \\
\hline Agrobacterium radiobacter & $\begin{array}{c}\text { Batch culture isolated from a } \\
\text { bench scale sequencing } \\
\text { batch reactor }\end{array}$ & 0.001 & 99.0 & [23] \\
\hline Pseudomonas spp. & Biofilter & $10-50$ & $90.0-95.0$ & [24] \\
\hline $\begin{array}{c}\text { Microorganisms attached to } \\
\text { bagasse }\end{array}$ & Biofilter (biomix) & - & 99.0 & [25] \\
\hline $\begin{array}{l}\text { Native bacteria from } \\
\text { seawater }\end{array}$ & Batch culture & 0.01 & 48.0 & [26] \\
\hline $\begin{array}{c}\text { Activated sludge of } \\
\text { wastewater treatment plant }\end{array}$ & Batch culture & $100-1000$ & - & [27] \\
\hline $\begin{array}{c}\text { Streptomyces sp., Bacillus } \\
\text { subtilis and Rhizobium } \\
\text { leguminosarum }\end{array}$ & Batch culture & 250 & $\begin{array}{l}89.7 \\
87.6 \\
86.2\end{array}$ & [28] \\
\hline Geobacillus caldoxylosilyticus & $\begin{array}{l}\text { Batch culture isolated from } \\
\text { central heating system water }\end{array}$ & 169.07 & - & [31] \\
\hline Biofilm & Laboratory aquarium & $0.01-0.1$ & $\begin{array}{l}\text { Complete } \\
\text { dissipation }\end{array}$ & [32] \\
\hline $\begin{array}{l}\text { Aspegillus oryzae } \\
\text { A-F02 }\end{array}$ & $\begin{array}{c}\text { Batch culture, isolated from } \\
\text { an aeration tank of a } \\
\text { pesticide factory }\end{array}$ & 1000 & - & [20] \\
\hline Fusarium oxysporum & $\begin{array}{l}\text { Platform shaker and Batch } \\
\text { bioreactor }\end{array}$ & 50 & 42.0 & [29] \\
\hline Trichoderma harzianum & Batch culture & 0.01 & 69.0 & [30] \\
\hline
\end{tabular}

\subsection{Psychochemical Treatment Processes}

Physicochemical processes are efficient and economical methods in pollutant removal from water and wastewater. Various physicochemical processes such as adsorption, membrane filtration, and coagulation have been studied at laboratory and pilot scales with the common target of removing glyphosate from water. However, adsorption and membrane filtration technologies have been widely studied. Some studies about the remotion of glyphosate from water polluted by psychochemical processes are summarized in Tables 2 and 3. 
Table 2. Removal of glyphosate from water polluted by adsorption process.

\begin{tabular}{|c|c|c|c|c|}
\hline \multicolumn{3}{|c|}{ Experimental Conditions } & \multirow{2}{*}{ Removal (\%) } & \multirow[b]{2}{*}{ Ref. } \\
\hline Adsorbent & Operating Conditions & $\begin{array}{l}\text { Glyphosate } \\
\text { Concentration } \\
\left(\mathrm{mg} \cdot \mathrm{a.i.} \cdot \mathrm{L}^{-1}\right)\end{array}$ & & \\
\hline $10 \mathrm{mg}\left(\mathrm{RGO} / \mathrm{Fe}_{3} \mathrm{O}_{4}\right)$ & $\begin{array}{l}\text { Batch scale, } \mathrm{pH} \text { solutions: } 4 \text {; } \\
\text { Solid/solution ratio: } 1 \mathrm{~g} \cdot \mathrm{L}^{-1}\end{array}$ & $40-40$ & 73.0 & [16] \\
\hline $\begin{array}{l}\text { Residual sludge from } \\
\text { industrial water }\end{array}$ & - & $\begin{array}{c}50-100 \\
200-500\end{array}$ & $\begin{array}{l}91.6 \\
97.4\end{array}$ & [33] \\
\hline $\begin{array}{c}\text { Metal organic } \\
\text { framework/grapheme oxide } \\
\text { hybrid nanocomposite } \\
(\mathrm{UiO}-67 / \mathrm{GO})\end{array}$ & $\begin{array}{c}\text { pH solutions: } 4 \text {; Treatment } \\
\text { time: } 3 \mathrm{~h}\end{array}$ & 2.560 & - & [34] \\
\hline Alum sludge & $\begin{array}{l}\text { Filter: Pot test filled with } \\
\text { adsorbents }\end{array}$ & 50 & 99.8 & [35] \\
\hline Cu-zeolite 4A & $\begin{array}{l}\text { Batch scale; Solid/solution } \\
\text { ratio: } 2 \mathrm{~g} \cdot \mathrm{L}^{-1}\end{array}$ & $50-150$ & - & [36] \\
\hline $\mathrm{GO}-\alpha-\gamma-\mathrm{Fe}_{2} \mathrm{O}_{3}$ & $\begin{array}{l}\text { Batch scale; Solid/solution } \\
\text { ratio: } 0.5-3.0 \mathrm{~g} \cdot \mathrm{L}^{-1}\end{array}$ & $1-80$ & 92.0 & [37] \\
\hline $\begin{array}{l}\text { Coconut shell activated } \\
\text { carbon and wood biochar }\end{array}$ & $\begin{array}{c}\text { Batch scale; Solid/solution } \\
\text { ratio: } 11.4 \mathrm{~g} \cdot \mathrm{L}^{-1} \text { and } 12.3 \\
\mathrm{~g} \cdot \mathrm{L}^{-1}\end{array}$ & $0.2-20$ & $\begin{array}{l}98.45 \\
100.0\end{array}$ & [38] \\
\hline Nano-CuFe ${ }_{2} \mathrm{O}_{4}$ modified & $\begin{array}{l}\text { Temperature: } 25^{\circ} \mathrm{C} ; \\
\text { Treatment time: } 4 \mathrm{~h} ; \mathrm{pH} \\
\text { solution: } 4\end{array}$ & 600 & 98.9 & [39] \\
\hline $\begin{array}{l}\text { D151 resin preloaded with } \\
\qquad \mathrm{Fe}^{3+}\end{array}$ & $\begin{array}{l}\text { Temperature: } 10-40{ }^{\circ} \mathrm{C} ; \\
\text { Treatment time: } 24 \mathrm{~h} ; \mathrm{pH} \\
\text { solution: } 3.35 ; \mathrm{NaCl} \\
\text { Concentration: } 16 \%\end{array}$ & $500-1100$ & - & [40] \\
\hline Montmorillonite- Fe(III) & $\begin{array}{c}\text { Batch scale: } \\
\text { Fe(III)-glyphosate 1:1 molar } \\
\text { ratio; } \mathrm{pH}>5.9 \text {; Treatment } \\
\text { time: } 3 \text { h; Agitation speed: } \\
150 \text { rpm }\end{array}$ & 350.0 & 98.05 & [41] \\
\hline $\begin{array}{l}\text { Kaolinite and } \\
\text { Kaolinite-humic acid } \\
\text { composite }\end{array}$ & $\begin{array}{l}\text { Batch scale; } 10 \mathrm{~g} \text { of sorbent; } \\
\text { Agitation speed: } 150 \mathrm{rpm} ; \\
\text { Treatment time: } 6 \mathrm{~h} ; \\
\text { Temperature: } 28^{\circ} \mathrm{C}\end{array}$ & 40.0 & - & [42] \\
\hline Montmorillonite & $\begin{array}{c}\text { Ionic strengths of } \mathrm{NaCl} \\
0-0.7 ; \mathrm{pH} \text { solution: } 2.0-9.0\end{array}$ & $0-169.07$ & - & [43] \\
\hline $\begin{array}{c}\text { Zr-based MOFs (NU-1000, } \\
\text { UiO-67) }\end{array}$ & $\begin{array}{c}\text { Batch scale; } 3 \text { mg of } \\
\text { activated MOFs; Treatment } \\
\text { Time: } 5 \text { h; mechanical } \\
\text { shaker: } 180 \mathrm{rpm}\end{array}$ & 1.7 & - & [44] \\
\hline
\end{tabular}


Table 3. Removal of glyphosate from water polluted by membrane filtration.

\begin{tabular}{|c|c|c|c|c|}
\hline \multicolumn{3}{|c|}{ Experimental Conditions } & \multirow{2}{*}{ Removal (\%) } & \multirow{2}{*}{ Ref } \\
\hline Membrane Filtration & Operating Conditions & $\begin{array}{c}\text { Glyphosate } \\
\text { Concentration } \\
\left(\mathrm{mg} \cdot \mathrm{a.i} \cdot \mathrm{L}^{-1}\right)\end{array}$ & & \\
\hline Organic GK NF membranes & $\begin{array}{c}\text { Cross-flow mode system; } \\
\text { Temperature: } 20^{\circ} \mathrm{C} ; \mathrm{pH} \\
\text { solution: } 2.96, \mathrm{TMP}: 2.5 \mathrm{MPa}\end{array}$ & 500 & 94.8 & [45] \\
\hline $\begin{array}{l}\text { Polyamide membranes: NFX } \\
\text { and NFY }\end{array}$ & $\begin{array}{c}\text { Temperature: } 25^{\circ} \mathrm{C} ; \mathrm{TMP}: \\
2.5 \mathrm{MPa}\end{array}$ & $\begin{array}{c}0.05 \\
0.049 * *\end{array}$ & $\begin{array}{l}82.8 \\
73.5\end{array}$ & [46] \\
\hline (TFC) Polyamide membrane & $\begin{array}{l}\text { Transversal-flow mode } \\
\text { system; pH solution: } 8.5 \text {; } \\
\text { TMP: 4-10 bar }\end{array}$ & 48.0 & 80.0 & [47] \\
\hline $\mathrm{GO} / \mathrm{TiO}_{2} / \mathrm{PSf}$ membranes & $\begin{array}{c}\text { Dead-end flow mode } \\
\text { system; } 25^{\circ} \mathrm{C}, \mathrm{TMP} 1 \text { bar }\end{array}$ & 20.0 & 53.0 & {$[48]$} \\
\hline
\end{tabular}

\subsubsection{Adsorption}

Adsorption has been widely studied due to its simplicity, low-cost, easy operation with high processing efficiency and high removal rates of most pollutants [16]. The key factor in this process is the adsorbent material selection, its performance is influenced by contaminant concentration, $\mathrm{pH}$, adsorption time, temperature, adsorbate doses and ion strength [16]. Over optimal conditions, the glyphosate adsorption mechanism occurs by means of physical and chemical interactions between functional groups in the glyphosate molecule $\left(-\mathrm{COOH},-\mathrm{NH}_{2}\right.$, and $\left.-\mathrm{PO}(\mathrm{OH})_{2}\right)$ and adsorbent surface.

- Physical adsorption is mainly caused by the forces of molecular interactions including permanent dipole/induced dipole, Van der Waals dispersion forces as well as hydrogen-bond with acid groups like $-\mathrm{OH}$ and $-\mathrm{COOH}$ on the material surface [16], but also it is caused by diffusion through a larger number of micro-, meso- and macro-pores with high pore volume [49].

- Chemical adsorption occurs due to electrostatic attraction between the glyphosate molecule and adsorbent surface, which is strongly influenced by $\mathrm{pH}$ conditions. In acidic conditions, glyphosate shows a negative charge, so it is attracted to the material's surface with a positive charge [16,49]. Additionally, onto iron-based adsorbents, the phosphonyl group of glyphosate molecule can make complexation with $\mathrm{Fe}^{2+}$ and $\mathrm{Fe}^{3+}$ ions forming stable single-tooth or bidentate complexes, thus facilitating the adsorption significantly [16].

A graphical representation of possible mechanisms for glyphosate adsorption is illustrated in Figure 2.

Many adsorbent materials have been studied for removing glyphosate from water and wastewater (Table 2). Current adsorption materials include activated carbon [50], bio-carbon [38], zeolite [36], goethite [50], alum sludge [33], graphene oxide and iron-based adsorbing materials [16]. Activated carbon was the first adsorbent studied for glyphosate remotion, it has only reached a range of efficiency of $12-20 \%$ [50,51]. However, under optimal parameters, a current study had reached the maximum removal capacity and efficiency of $98.45 \%$ using coconut shell activated carbon [35]. Activated bio-carbon produced from rice husk (RHBC) and wood biochar have shown $82 \%$ and $100 \%$ as maximum removal efficiency at $\mathrm{pH} 4.0$ and $\mathrm{pH} 5.0$ respectively $[38,50]$. Both adsorbents have shown that adsorption capacity reduces significantly with the increase in $\mathrm{pH}$. On the other hand, glyphosate adsorption using both zeolite $(\mathrm{Al})$ and goethite $(\mathrm{Fe})$ mineral surfaces is generally explained by the formation of complexes [52]. Recently, a study has modified zeolite with cupric ion (Cu-zeolite 4A) in order to improve adsorption capacity; the maximum adsorption capacity for Cu-zeolite $4 \mathrm{~A}$ was $112.7 \mathrm{mg} \cdot \mathrm{g}^{-1}$ based on the Langmuir model [36]. 


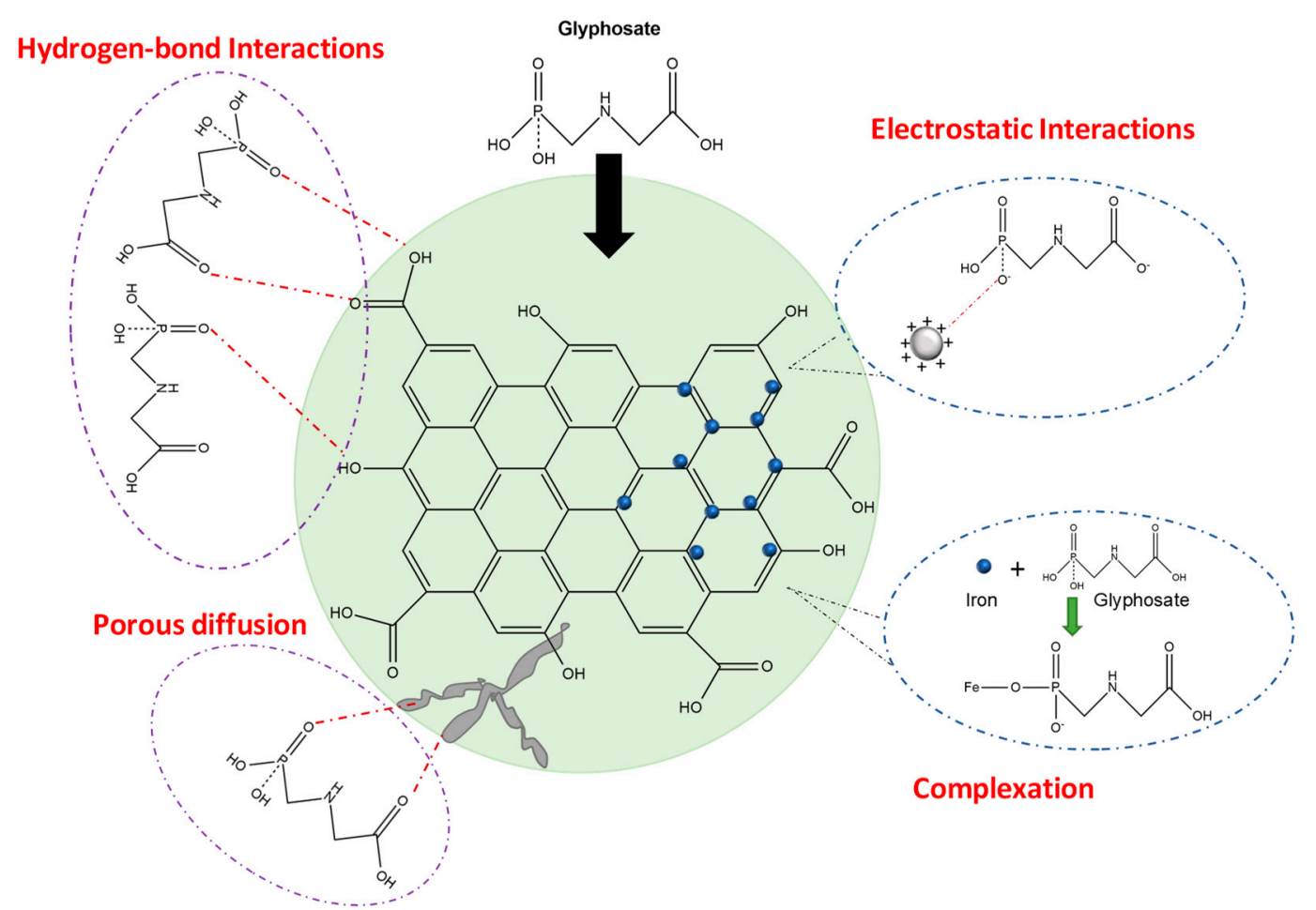

Figure 2. Glyphosate adsorption mechanism of carbon absorbents and iron-based adsorbents.

Alum sludge has exhibited the potential to be an efficient and cost-effective adsorbent for glyphosate removal with excellent immobilization ability, two studies have used it as an adsorbent. The first study reported a maximum glyphosate adsorption capacity calculated from Langmuir's isotherm of $85.9 \mathrm{mg} \cdot \mathrm{g}^{-1}$ for dewatered alum sludge (DAS) and $113.6 \mathrm{mg} \cdot \mathrm{g}^{-1}$ for liquid alum sludge (LAS), with a removal efficiency of $91.6 \%$ and $97.4 \%$ respectively [33], and the second exhibited an average glyphosate removal of $99.8 \%$ over 10 -week test period [35]. Additionally, graphene oxide has excellent adsorption performances for many pollutants, but it is difficult to be recovered from the water after the treatment process. Thus, it is combined with magnetic iron-based adsorbents for an easy separation process. For instance, nanoscale graphene oxide combined with $\mathrm{Fe}_{3} \mathrm{O}_{4}$ to obtain magnetic reduced graphene $\left(\mathrm{RGO} / \mathrm{Fe}_{3} \mathrm{O}_{4}\right)$; could achieve a satisfactory adsorption performance for low GLY concentrations ( $1-40 \mathrm{mg} \cdot \mathrm{L}^{-1}$ ) with removal rates higher than $86 \%$ by adding $10 \mathrm{mg}$ of $\mathrm{RGO} / \mathrm{Fe}_{3} \mathrm{O}_{4}$ [16], and graphene oxide combined with magnetic nanoparticles of iron oxide to obtain graphene oxide functionalized by magnetic nanoparticles of iron $\left(\alpha-\gamma-\mathrm{Fe}_{2} \mathrm{O}_{3}\right)$; which after $2 \mathrm{~h}$ of equilibrium time the maximum removal was $92 \%$ at $15^{\circ} \mathrm{C}$ [37].

Montmorillonite is a 2:1 type aluminosilicate that has been proposed as an adsorbent for glyphosate removal. Glyphosate molecules accommodate between the layers which increases the interlayer space, XRD patterns show a displacement in the peak that corresponds to (001) plane due to the intercalation compound formation. Adsorption of glyphosate in montmorillonite may be enhanced by the presence of $\mathrm{Fe}(\mathrm{III})$, the maximum adsorption capacity was greater than $210 \mathrm{mg} \cdot \mathrm{g}^{-1}$ showing great potential for high glyphosate concentrations removal in wastewater [41]. Kaolinite is another clay mineral which can act as GLY adsorbent, GLY interacts with kaolinite surface by the creation of a hydrogen bonds network. Humic acids may enhance the adsorption by the formation of a composite kaolinite-humic acid [42].

As can be observed, even though the adsorption process seems to be an effective way to remove glyphosate from water, the majority of reports have been studied at laboratory scales using synthetic water. Additionally, the main disadvantage of water treatment by adsorption is the residue produced and the not-easy reuse of adsorbents. Thus, in order to scale adsorption technology, it requires to 
promote the efficiency of adsorbents for glyphosate removal in natural waters and the recovery of adsorbents after-treatment process. Modification of the existing low-cost adsorbents is one of the most significant strategies to improve their performance; however, the main challenge with the use of adsorbents is their low selectivity by co-existing compounds in real water samples. Therefore, the design of an adsorbent with enhanced both capacity and selectivity can be considered as one of the most important research objectives for glyphosate remotion from water. Finally, adsorption treatment has some disadvantages the adsorption efficiency of glyphosate has been better at acidic $\mathrm{pH}$ levels, this has implications at the treatment plant application because it determines $\mathrm{pH}$ adjustment of the influent.

\subsubsection{Membrane Filtration}

Over the last few years, membrane filtration technologies have been used in many areas of water and wastewater treatment. This system works as a barrier for matter transport of an influent stream and separates it into two effluent streams: the permeate and the retentate or concentrate $[45,53]$. The nanofiltration process has been applied to remove dissolved organic matter, color, and pesticides from aqueous media [46,47]. However, there are very few reports above glyphosate removal using nanofiltration technology. A summary of the removal of glyphosate from water polluted by membrane filtration is presented in Table 3.

Liu et al. [45] and Saitúa et al. [47] were the first studies about glyphosate removal by nanofiltration process. Liu et al. [45] conducted experiments of glyphosate separation using nanomembrane with cross-flow filtration from simulated wastewater, under experimental conditions $\left(20{ }^{\circ} \mathrm{C}, \mathrm{pH} 2.96\right.$, time $30 \mathrm{~min}$, trans-membrane pressure $2.5 \mathrm{MPa}$ ) it reached $94.8 \%$ of glyphosate retention [45]. On the other hand, Saitúa et al. [47] worked with commercial formulations of glyphosate in synthetic and natural waters using transversal flow nanofiltration treatment plants and reached glyphosate-removal over $80 \%$ in distilled water and a similar value for river water [47]. Neither of them did include the effect of coexisting matter such as AMPA, humic acid and calcium salts, which are ubiquitous components of aquatic environments and influence the fate and the behavior of micropollutants as well as its removal by nanofiltration [46]. A schematic diagram of the experimental setup is shown in Figure 3.

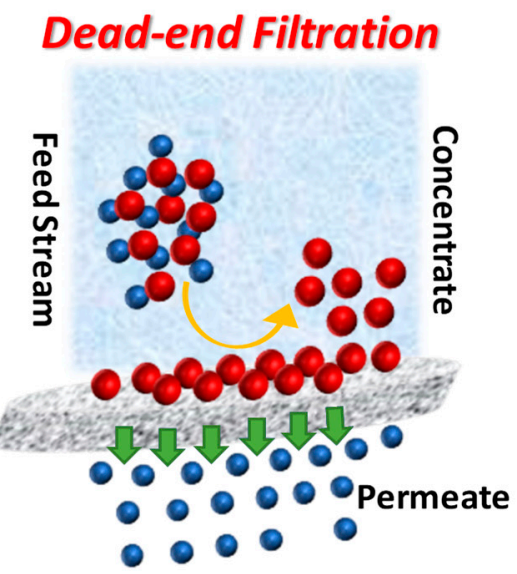

\section{Cross-flow Filtration}

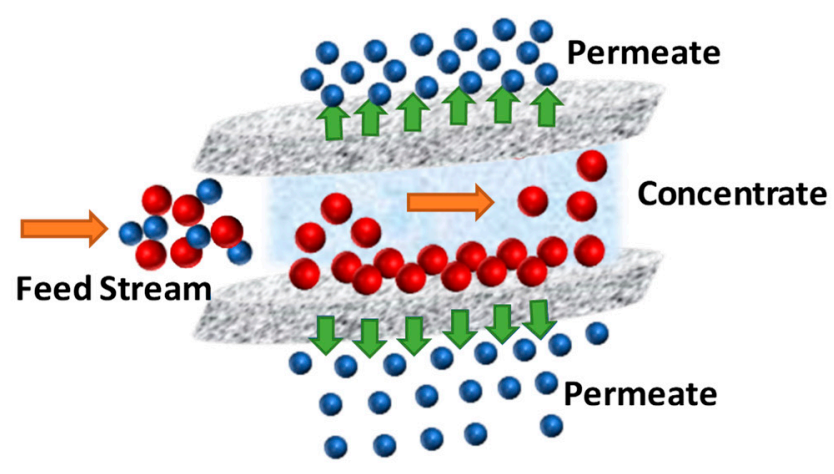

Figure 3. A schematic diagram of glyphosate nanofiltration in aqueous system: dead-end flow and crossflow filtration.

Therefore, there is a need for evaluating the effect of natural organic matter on glyphosate removal by nanofiltration. Yuan et al. [46] conducted experiments using two types of commercial thin-film polyamide nanofiltration membranes (NFX, NFY) to remove glyphosate and AMPA from simulated water and included the effect of coexisting matters such as AMPA, humic acid and calcium salts $\left(\mathrm{CaCl}_{2} \mathrm{y} \mathrm{NaCl}\right)$. The results demonstrated that with an initial concentration of $50 \mu \mathrm{g} \cdot \mathrm{L}^{-1}$ and 
2.5 $\mathrm{MPa}$ of trans-membrane pressure (TMP), the rejection percent is $82.8-91.5 \%$ for glyphosate and 73.5-86.7\% for AMPA. Intermediate concentrations of $\mathrm{NaCl}$ and humic acid showed little influence on the glyphosate-retention; on the contrary, $\mathrm{CaCl}_{2}$ shown a negative effect during the nanofiltration process. However, rejection performance slightly improved when coexisted humic acid and $\mathrm{CaCl}_{2}[46]$. Finally, this work clearly shows that the composition of the water matrices may influence the efficiency of the nanofiltration process in terms of the micropollutants separation.

The modification of adsorbents structure by means of advanced nanocomposite materials to obtain mixed matrix membranes has been also applied in ultra/nanofiltration systems. Hosseini and Toosi [48], synthesized a nanocomposite of graphene oxide and titanium dioxide $\left(\mathrm{GO} / \mathrm{TiO}{ }_{2}\right)$ and mixed it with polysulfone membranes (PSf); GO/TiO $2 / \mathrm{PSf}$ membranes were used for dead-end flow ultrafiltration system of some commercial herbicides, one of them was glyphosate, from aqueous solutions. The results showed that blended membranes acted based on the size molecule exclusion mechanism and $\mathrm{GO} / \mathrm{TiO}_{2}$ nanoparticles in membrane played a key role in the percentage of adsorption of herbicides on $\mathrm{GO} / \mathrm{TiO}_{2} / \mathrm{PSf}$ membrane. Glyphosate rejection was 53\% working under the following experimental conditions: dead-end flow ultrafiltration system, glyphosate concentracion (20 ppm), TMP 1 bar and constant temperature $\left(25^{\circ} \mathrm{C}\right)$.

In general, filtration by polymeric membranes seems to be an effective method for the removal of pollutants from water, but there is a lack of knowledge about the operation process because neither of the studies has been done in real water. Therefore, there is still room for investigation researching the feasibility of using the nanofiltration process to remove glyphosate from water. Membrane filtration could present some advantages. One of them is that the filtration process does not destroy pollutant molecules so it does not produce harmful intermediates which could be more toxic than original pollutants, another advantage is that the pollutant could be recovered after saturation of membranes. On the other hand, a disadvantage of membrane filtration could be its specificity to reject specific pollutants, but in real conditions, the composition and characteristics of water could suddenly change affecting the efficiency of the filtration process. Therefore, there is a need for evaluating with more detail the effect of natural organic matter on glyphosate removal by nanofiltration and the effectiveness of this treatment for polluted water with commercial formulations because adjuvants (surfactants) could not be rejected if this process were applied in real conditions of polluted water.

\subsection{Advanced Oxidation Processes (AOPS)}

AOPs have been proposed as alternative methods for water and wastewater treatment, which usually operate at or near ambient temperature and pressure conditions, and they involve the generation of powerful oxidizing agents in sufficient quantity to effective water purification [54]. The AOPs gather numerous techniques based on the in-situ formation of strong oxidants. Among, those radicals, the hydroxyl radical $\left({ }^{\bullet} \mathrm{OH}\right)$ plays a central role in AOPs due to its high standard potentials ( $2.8 \mathrm{~V}$ vs. $\mathrm{NHE}$ ) in acidic media. It is highly reactive and nonselective that can oxidize and decompose organic matter until its total mineralization $\mathrm{CO}_{2}, \mathrm{H}_{2} \mathrm{O}$, and its corresponding inorganic salt [54,55]. In the case of glyphosate molecule, its degradation is attributed to the attack of ${ }^{\bullet} \mathrm{OH}$ that lead to cleavage of the $\mathrm{C}-\mathrm{N}$ and $\mathrm{C}-\mathrm{P}$ bonds to yield intermediaries such as AMPA and sarcosine or final degradation products such as nitrate, ammonium and phosphate ions, carbon dioxide, and water (Reaction 1). Among AOPs strategies employed to remove glyphosate from water are Fenton and Photo-Fenton process, ozonization $\left(\mathrm{O}_{3}\right)$, photocatalysis, photolysis with hydrogen peroxide and UV light $\left(\mathrm{H}_{2} \mathrm{O}_{2}-\mathrm{UV}\right)$, electrochemical oxidation and photoelectrochemical processes [54-56]. The mechanism of some AOPs applied to remove glyphosate from water are explained below and some studies about the degradation of glyphosate by AOPs are summarized in Table 4.

$$
\mathrm{C}_{3} \mathrm{H}_{8} \mathrm{NO}_{5} \mathrm{P}+{ }^{\bullet} \mathrm{OH} \rightarrow \mathrm{CO}_{2}+\mathrm{H}_{2} \mathrm{O}+\mathrm{NO}_{3}{ }^{-}+\mathrm{NH}_{4}{ }^{+}+\mathrm{PO}_{4}{ }^{3-}
$$


Table 4. Removal of glyphosate from water polluted by advanced oxidation processes (AOPs).

\begin{tabular}{|c|c|c|c|c|}
\hline AOPs & Operating Conditions & $\begin{array}{l}\text { Glyphosate } \\
\text { Concentration } \\
\left(\mathrm{mg} \mathrm{a.i.}^{-1}\right)\end{array}$ & Removal (\%) & Ref. \\
\hline UV/Ferrioxalate & $\begin{array}{c}\mathrm{V}=80 \mathrm{~mL} \text { (eight quartz tubes } / 10 \mathrm{~mL}) \\
\mathrm{pH}=3.5-6.0 ; \mathrm{UV} \text {-vis Lamp } 250 \mathrm{~W} \\
(\lambda \geq 365 \mathrm{~nm}) ; \mathrm{t}=180 \mathrm{~min}\end{array}$ & $1.0-5.0$ & - & [57] \\
\hline $\mathrm{UV} / \mathrm{TiO}_{2}$ & $\begin{array}{l}\mathrm{V}=400 \mathrm{~mL} \text { (cylindrical annular-type } \\
\text { reactor); } \mathrm{pH} \text { from } 2.0 \text { to } 12.0 \text {; UV Lamp }= \\
365 \mathrm{~nm} \text {; illumination time }=1 \mathrm{~h}\end{array}$ & 42.25 & $9.8-50.2$ & [15] \\
\hline $\begin{array}{c}\text { Photocatalytic } \\
\text { degradation }\left(\mathrm{UV}-\mathrm{TiO}_{2}\right)\end{array}$ & $\begin{array}{c}\mathrm{V}=200 \mathrm{~mL} ; \text { high-pressure mercury lamp } \\
(125 \mathrm{~W}, \lambda>290 \mathrm{~nm}) ; \text { amount of catalyst }= \\
0.1 \mathrm{~g} \cdot \mathrm{L}^{-1} \text { of } \mathrm{TiO}_{2} ; \mathrm{t}=30 \mathrm{~min} .\end{array}$ & 42.3 & 99.9 & [58] \\
\hline $\mathrm{H}_{2} \mathrm{O}_{2} / \mathrm{UV}$ & $\begin{array}{l}\mathrm{V}_{\text {reactor }}=110 \mathrm{~cm}^{3} ;\left[\mathrm{H}_{2} \mathrm{O}_{2}\right]=75-200 \\
\mathrm{mg} \cdot \mathrm{L}^{-1} ; \mathrm{t}=5 \mathrm{~h} ; 2 \mathrm{UV} \text { lamp of } 40 \mathrm{~W}\end{array}$ & 50.0 & 70.0 & [59] \\
\hline Photocatalysis $\mathrm{Ce}-\mathrm{TiO}_{2}$ & $\begin{array}{c}0.15 \% \mathrm{Ce}-\mathrm{TiO}_{2} \text { nanotubes annealed at } \\
400{ }^{\circ} \mathrm{C} ; \mathrm{V}=500 \mathrm{~mL} ; \mathrm{t}=1 \mathrm{~h} ; \mathrm{pH}=7 ; 125 \\
\text { high-pressure mercury lamps. }\end{array}$ & 22.8 & 76.0 & [60] \\
\hline $\begin{array}{c}\mathrm{UV} / \mathrm{H}_{2} \mathrm{O}_{2} \\
\text { experimental and } \\
\text { mathematical model }\end{array}$ & $\begin{array}{c}\mathrm{V}=2000 \mathrm{~mL} \text { (quartz cylindrical reactor, } \\
110 \mathrm{~mL} \text {, with recirculation); flow rate }= \\
5 \times 10^{-2} \mathrm{~cm}^{3} \cdot \mathrm{s}^{-1} ; \mathrm{UV} \text { Lamp }=253.7 \mathrm{~nm} ; \\
\mathrm{pH}=5.2 ;\left[\mathrm{H}_{2} \mathrm{O}_{2}\right]=0 \text { to } 403 \mathrm{mg} \cdot \mathrm{L}^{-1} ; \\
\mathrm{t}=12 \mathrm{~h}\end{array}$ & 140.0 & $\begin{array}{l}80.0 \text { GLY } 70.0 \\
\text { TOC }\end{array}$ & [61] \\
\hline $\mathrm{UV} / \mathrm{H}_{2} \mathrm{O}_{2}$ & $\begin{array}{l}\mathrm{V}=1000 \mathrm{~cm}^{3} ; \text { two low-pressure mercury } \\
\text { vapor lamps with one emission } \\
\text { wavelength at } \lambda=253.7 \mathrm{~nm} ; \\
Q=2 \mathrm{~L} \cdot \mathrm{s}^{-1} ; \mathrm{t}=8 \mathrm{~h}\end{array}$ & 30.0 & - & [62] \\
\hline UV/Goethite & $\begin{array}{l}\text { incident light intensity } 500-2000 \mathrm{~W} / \mathrm{m}^{2} \\
\mathrm{~T}=20^{\circ} \mathrm{C} \text {, pH 3-9 }\end{array}$ & 10.0 & $\begin{array}{l}92.0 \\
99.3\end{array}$ & [63] \\
\hline $\begin{array}{l}\text { Aeroxide } \\
\mathrm{TiO}_{2}-\mathrm{P} 25\end{array}$ & $\begin{array}{c}\text { Volume } 250 \mathrm{~mL} \text {, stirring } 600 \mathrm{rpm}, \mathrm{UV}-\mathrm{A} \\
\text { light } 60 \mathrm{~W} / \mathrm{m}^{2} \text { wavelength at } \lambda=365 \mathrm{~nm} \text {, } \\
\text { Time }=240 \mathrm{~min}\end{array}$ & 25.0 & 100 & [64] \\
\hline $\begin{array}{l}\text { Photochemical } \\
\text { degradation over } \\
\mathrm{CuS} / \mathrm{Bi}_{2} \mathrm{WO}_{6}\end{array}$ & $\begin{array}{l}\text { Hierarchical } \mathrm{CuS} / \mathrm{Bi}_{2} \mathrm{WO}_{6} \text { p-n junction } \\
\text { photocatalyst; illumination time: } 180 \mathrm{~min} \text {; } \\
44 \mathrm{~W} \text { light-emitting diode (LED) light } \\
\text { irradiation }(\lambda>400 \mathrm{~nm})\end{array}$ & 16.9 & 85.9 & [65] \\
\hline Photo-Fenton & $\begin{array}{c}\mathrm{V}=50 \mathrm{~L} \text {; closed recirculating system at a } \\
\text { flow rate of } 2.37 \mathrm{~L} \cdot \mathrm{min}^{-1} ;\left[\mathrm{Fe}^{2+]} \text { or }\right. \\
{\left[\mathrm{Fe}^{2+} / \mathrm{Fe}^{3+}\right]=0.27 \mathrm{mmol} \cdot \mathrm{L}^{-1} ;} \\
{\left[\mathrm{H}_{2} \mathrm{O}_{2}\right]=10.3 \mathrm{mmol} \cdot \mathrm{L}^{-1} ; \text { pH } 2.8 \pm 0.2}\end{array}$ & $\begin{array}{l}100.0 \\
100.0\end{array}$ & - & [66] \\
\hline Electro-Fenton $\mathrm{Mn}^{2+}$ & $\begin{array}{c}\mathrm{V}=200 \mathrm{~mL} ; 100 \mathrm{~mA} \text { constant current; } \\
\text { catalyst }=0.1 \mathrm{mM} \mathrm{Mn}^{2+}\end{array}$ & 22.8 & $92.0-100.0$ & [67] \\
\hline Electro-Fenton & $\begin{array}{l}\mathrm{t}=360 \mathrm{~min} ; \mathrm{pH}=3 \\
\text { current intensity }=0.36 \mathrm{~A} ; 1 \mathrm{mM} \text { of } \mathrm{Fe}^{2+} \\
\text { pure } \mathrm{O}_{2} \text { flow rate }=100 \mathrm{~mL} \cdot \mathrm{min}^{-1}\end{array}$ & 22.8 & - & [68] \\
\hline $\begin{array}{c}\text { Electrochemical } \\
\text { oxidation with } \\
\mathrm{RuO}_{2} / \mathrm{IrO}_{2} \text { electrodes }\end{array}$ & $\begin{array}{l}\mathrm{i}=50 \mathrm{~mA} \cdot \mathrm{cm}^{-2} ; \mathrm{t}=4 \mathrm{~h} ; \text { electrode } \\
\text { composition }=\mathrm{Ti} / \mathrm{Ir}_{0.30} \mathrm{Sn}_{0.70} \mathrm{O}_{2}\end{array}$ & 1000.0 & 24.0 & [69] \\
\hline $\begin{array}{l}\text { Adsorption and POA's } \\
\qquad\left(\mathrm{H}_{2} \mathrm{O}_{2}\right)\end{array}$ & $\begin{array}{l}\mathrm{V}=150 \mathrm{~mL} \text { of glyphosate residue } \\
\text { solution; } \mathrm{pH}=2-4 ; \text { adsorbent }= \\
\text { nano-tungsten/D201 resin }+\mathrm{H}_{2} \mathrm{O}_{2}\end{array}$ & 258.0 & 60.5 & [70] \\
\hline $\begin{array}{l}\text { Electrochemical } \\
\text { degradation with } \\
\qquad \mathrm{MnO}_{2}\end{array}$ & $\begin{array}{c}\mathrm{V}=400 \mathrm{~mL} ; \text { acidic } \mathrm{pH} ; \mathrm{i}=10 \mathrm{~mA} \cdot \mathrm{cm}^{-2} \\
\mathrm{t}=120 \mathrm{~min}\end{array}$ & 22.8 & 80.0 & [71] \\
\hline
\end{tabular}


Table 4. Cont.

\begin{tabular}{|c|c|c|c|c|}
\hline AOPs & Operating Conditions & $\begin{array}{l}\text { Glyphosate } \\
\text { Concentration } \\
\left(\mathrm{mg} \text { a.i. } \mathrm{L}^{-1}\right)\end{array}$ & Removal (\%) & Ref. \\
\hline $\begin{array}{l}\text { Electrochemical } \\
\text { degradation }\end{array}$ & $\begin{array}{l}\text { Anode: } \mathrm{Ti} / \mathrm{PbO}_{2} ; \mathrm{pH} \text { : 3-10; current } \\
\text { intensity: } 4.77 \mathrm{~A} \text {; reaction time: } 173 \mathrm{~min} \text {; } \\
\text { electrolyte: } \mathrm{Na}_{2} \mathrm{SO}_{4}\end{array}$ & $4-16$ & 95.16 & [72] \\
\hline $\begin{array}{l}\text { Electrochemical } \\
\text { oxidation BDD }\end{array}$ & $\begin{array}{l}\text { Electric charge }=6.0 \mathrm{Ah} \cdot \mathrm{dm}^{-3} ; \text { glyphosate } \\
\text { pure; } \mathrm{t}=\text { about } 150 \mathrm{~min} ; \text { Chloride media }\end{array}$ & 100.0 & - & [73] \\
\hline $\begin{array}{l}\text { Photochemical } \\
\text { Oxidation with BDD }\end{array}$ & $\begin{array}{c}\text { UV lamp }(\lambda=254 \mathrm{~nm}) ; \mathrm{i}=100 \mathrm{~mA} \cdot \mathrm{cm}^{-2} ; \\
t=\text { about } 200 \mathrm{~min} ; \\
\text { supporting electrolyte }=\mathrm{NaCl}\end{array}$ & 100.0 & - & [74] \\
\hline
\end{tabular}

\subsubsection{Fenton-Based Treatment Process}

Fenton and Photo-Fenton processes have the ability to decompose toxic organic molecules in water and wastewaters by means of strong oxidant species produced in aqueous media. The Fenton process utilizes ferrous $\left(\mathrm{Fe}^{2+}\right)$ ion as a catalyst to decompose hydrogen peroxide $\left(\mathrm{H}_{2} \mathrm{O}_{2}\right)$ and convert it to ${ }^{\bullet} \mathrm{OH}$ radicals [75]. The generally accepted mechanism of the Fenton process is based on Reaction 2 .

$$
\mathrm{Fe}^{2+}+\mathrm{H}_{2} \mathrm{O}_{2} \rightarrow \mathrm{Fe}^{3+}+\cdot{ }^{\bullet} \mathrm{OH}+\mathrm{OH}^{-}
$$

Based on the classical Fenton treatment process and in order to enhance the degradation efficiency, some hybrid processes based on Fenton's reaction (Equation (2)) such as photo-Fenton system and electro-Fenton system have been proposed [75]. In the photo-Fenton reaction, ultraviolet or visible light irradiation is applied with the traditional Fenton system with a major purpose of enhancing the production of ${ }^{\bullet} \mathrm{OH}$ from photolysis of $\mathrm{H}_{2} \mathrm{O}_{2}$ (Reaction 2) and UV-induced reduction of dissolved $\mathrm{Fe}^{3+}$ to $\mathrm{Fe}^{2+}$ (Reaction 4) [55].

$$
\begin{aligned}
\mathrm{H}_{2} \mathrm{O}_{2}+h v & \rightarrow 2^{\bullet} \mathrm{OH} \\
\mathrm{Fe}^{3+}+h v & \rightleftarrows \mathrm{Fe}^{2+}
\end{aligned}
$$

In the same context, in electro-Fenton technology, either or both Fenton reagents $\left(\mathrm{H}_{2} \mathrm{O}_{2}\right.$ and $\left.\mathrm{Fe}^{2+}\right)$ may be generated through electrochemical reactions, according to Reaction 5 and Reaction 6.

$$
\begin{gathered}
\mathrm{O}_{2}+2 \mathrm{H}^{+}+2 \mathrm{e}^{-} \rightleftarrows \mathrm{H}_{2} \mathrm{O}_{2} \\
\mathrm{Fe}^{3+}+\mathrm{e}^{-} \rightleftarrows \mathrm{Fe}^{2+}
\end{gathered}
$$

There are a few reports on the above-mentioned Fenton's reaction applied to remove glyphosate from water, some of them are shown in Table 4. Chen et al. [57], in their study, report a ferrioxalate system under UV irradiation (metal halide lamp, $250 \mathrm{~W}, \lambda \geq 365 \mathrm{~nm}$ ). Under this system, the degradation of glyphosate was about $60 \%$ after $180 \mathrm{~min}$ of UV irradiation when the initial concentration of the pollutant was $5.0 \mathrm{mg} \cdot \mathrm{L}^{-1}$ and the $\mathrm{pH}$ of the solution was 3.5 [57]. Souza et al. [66] studied the degradation of glyphosate by the Photo-Fenton process under optimized conditions at lab-scale $\left(0.27 \mathrm{mmol} \cdot \mathrm{L}^{-1}\right.$ of $\mathrm{Fe}^{2+} / \mathrm{Fe}^{3+}$; $1.13 \mathrm{mmol} \cdot \mathrm{L}^{-1}$ oxalate; $10.3 \mathrm{mmol} \cdot \mathrm{L}^{-1} \mathrm{H}_{2} \mathrm{O}_{2}$ and $\mathrm{pH} 2.8 \pm 0.2,400 \mathrm{~W}$ high-pressure mercury vapor lamp). After $60 \mathrm{~min}$ of photo-Fenton process glyphosate concentration fell down below reaching a remotion of $57 \%$ of total organic carbon (TOC) and $0.385 \mathrm{mmol} \cdot \mathrm{L}^{-1}$ phosphate ion as a final degradation product. Additionally, they reported that the toxicity of effluent decreased from $100 \%$ to $54 \%$ due to less concentration of glyphosate [66]. Recently, Serra-Clusellas et al. [76] have explored the solar photo-Fenton-like (SPF-like) process for the remotion of $1 \mathrm{mg} \cdot \mathrm{L}^{-1}$ of glyphosate and AMPA using low $\mathrm{Fe}(\mathrm{II})$ or $\mathrm{Fe}(\mathrm{III})$ concentrations. Under these conditions, SPF-like and SPF processes led them to reach $70 \%$ and $80 \%$ mineralization, respectively. 
On the other hand, electro-Fenton-like treatment with $\mathrm{Mn}^{2+}$ as a catalyst achieved complete removal of the herbicide $(0.1 \mathrm{mM})$ after $60 \mathrm{~min}$ at $200 \mathrm{~mA}$ of current applied. Under this process, AMPA was the principal degradation intermediary [67]. Another application of Electro-Fenton was reported by Lan et al. [68] where activated carbon fiber (ACF) was used as a cathode; under optimum operation conditions $\left(t=360\right.$ min; $\mathrm{pH}=3$; current intensity $=0.36 \mathrm{~A} ; 1 \mathrm{mM}$ of $\mathrm{Fe}^{2+}$; pure $\mathrm{O}_{2}$ flow rate $=100 \mathrm{~mL} \cdot \mathrm{min}^{-1}$ ), it achieved a $50.4 \%$ of total organic carbon (TOC) remotion and a $72 \%$ of chemical organic demand (COD) remotion. The most recent application of Fenton-process using carbon felt cathode showed that the maximal removal percentage of glyphosate was $91.91 \%$ with an applied current density of $10 \mathrm{~mA} \cdot \mathrm{cm}^{-2}, \mathrm{pH} 3,0.1 \mathrm{mM} \mathrm{Fe}{ }^{2+}, 0.05 \mathrm{M} \mathrm{Na}_{2} \mathrm{SO}_{4}$, and $0.1 \mathrm{mM}$ as glyphosate concentration under $40 \mathrm{~min}$ of treatment. However, only $81.65 \%$ of TOC decayed in the same conditions due to the production of some intermediates during the electro-Fenton process that could be more slowly degraded than glyphosate [77]. As has been noted, the Fenton-based process has not been vastly studied as a treatment technology to remove glyphosate from water. This is likely because it requires strict control of operational conditions, as acidic medium ( $\mathrm{pH}$ 2.8-3.0), and the efficiency of mineralization is not good due to the formation of degradation intermediaries which could be more toxic than glyphosate. Additionally, the Fenton process has been studied only under laboratory conditions using synthetic water, so it requires more studies with water conditions that could be found in real water polluted with glyphosate.

\subsubsection{UV-Based Treatment Process}

UV-based processes require yields that leads to enough quantities of powerful oxidizing species to degrade pollutants in water. Photolysis $\left(\mathrm{UV} / \mathrm{H}_{2} \mathrm{O}_{2} ; \mathrm{UV} / \mathrm{O}_{3}\right)$ and heterogeneous photocatalysis are two UV-based processes studied to remove glyphosate from water polluted [55].

During vacuum-ultraviolet (V-UV, $\lambda=172 \mathrm{~nm}$ ) the photolysis of pure water is a particularly interesting or powerful source of ${ }^{\bullet} \mathrm{OH}$ radicals that can degrade pollutants in water, according to Reaction 7. According to Azrague et al. [78], this technique presents the advantage of producing ${ }^{\bullet} \mathrm{OH}$ without the addition of any supplementary oxidant (e.g., hydrogen peroxide or ozone) or catalyst. However, ultraviolet light combined with hydrogen peroxide $\left(\mathrm{UV} / \mathrm{H}_{2} \mathrm{O}_{2}\right)$ (Reaction 3) or combined with ozone $\left(\mathrm{UV} / \mathrm{O}_{3}\right)$ increases the quantity of $\bullet \mathrm{OH}$ radicals produced [75]. According to Wang and $\mathrm{Xu}$ [55], upon photolysis $(\lambda<300 \mathrm{~nm}), \mathrm{O}_{3}$ is decomposed into $\mathrm{O}_{2}$ and oxygen atom $\mathrm{O}\left({ }^{1} \mathrm{D}\right) . \mathrm{O}\left({ }^{1} \mathrm{D}\right)$ is very energetic and therefore reacts fast with practically all conceivable substrates, including water to form $\mathrm{H}_{2} \mathrm{O}_{2}$ via Reaction 8. To end the reaction process, $\mathrm{H}_{2} \mathrm{O}_{2}$ could form oxidant species based on Reaction 3.

$$
\begin{gathered}
\mathrm{H}_{2} \mathrm{O}+h v(\mathrm{~V}-\mathrm{UV}) \rightarrow{ }^{\bullet} \mathrm{OH}+\mathrm{H}^{\bullet} \\
\mathrm{O}_{3}+\mathrm{H}_{2} \mathrm{O}+h v \rightarrow \mathrm{H}_{2} \mathrm{O}_{2}+\mathrm{O}_{2}
\end{gathered}
$$

Another treatment process studied to remove glyphosate from water is heterogeneous photocatalysis. The photocatalytic process has been a successful technology for glyphosate degradation, and in this process, the semiconductor catalyst most widely used is titanium dioxide $\left(\mathrm{TiO}_{2}\right)$ [79]. Its photocatalytic activity occurs by photons irradiation with energy equal to or greater at semiconductor band-gap energy ( $\mathrm{h} v \geq \mathrm{Eg}$ ), being $3.25 \mathrm{eV}$ for $\mathrm{TiO}_{2}$ in anatase phase or $3.05 \mathrm{eV}$ in the rutile phase. The irradiation causes the electrons $\left(\mathrm{e}^{-}\right)$of the valence band (VB) to exit and migrate to the conduction band (CB) leaving vacancies or positively charged holes $\left(\mathrm{h}^{+}\right)$in the BV. In this way, electron/hole pairs $\left(\mathrm{e}_{\mathrm{CB}}{ }^{-} / \mathrm{h}_{\mathrm{VB}}{ }^{+}\right)$, where redox reactions are carried out, are generated (Reaction 9). The $\mathrm{h}_{\mathrm{VB}}{ }^{+}$are strong oxidizing agents where water oxidation reaction form ${ }^{\bullet} \mathrm{OH}$ radicals or react directly with pollutants on semiconductor surface (Reaction 10); while the $\mathrm{e}_{\mathrm{CB}}{ }^{-}$react with electron receptor species such as $\mathrm{O}_{2}$ to form superoxide radicals $\left(\mathrm{O}_{2}{ }^{\bullet-}\right)$, which also is an oxidant species (Reaction 11) [80].

$$
\mathrm{TiO}_{2}+h v \rightarrow \mathrm{TiO}_{2\left(\mathrm{e}_{\mathrm{CB}}{ }^{-} / \mathrm{h}_{\mathrm{VB}}{ }^{+}\right)}
$$




$$
\begin{gathered}
\mathrm{TiO}_{2\left(\mathrm{~h}_{\mathrm{VB}}^{+}\right)}+\mathrm{H}_{2} \mathrm{O} \rightarrow{ }^{\bullet} \mathrm{OH}+\mathrm{H}^{+}+\mathrm{e}^{-} \\
\mathrm{TiO}_{2\left(\mathrm{e}_{\mathrm{CB}}^{-}\right)}+\mathrm{O}_{2} \rightarrow \mathrm{O}_{2}^{\bullet-}
\end{gathered}
$$

Based on the mechanism described above, some studies about glyphosate removal from water by photolysis and heterogeneous photocatalytic process are analyzed below and summarized in Table 4 .

Manassero et al. [59] studied the $\mathrm{H}_{2} \mathrm{O}_{2} /$ UVC process performed with glyphosate solutions in the concentration of $0.30 \mathrm{mM}$ and $0.45 \mathrm{mM}$ or $50-75 \mathrm{mg} \cdot \mathrm{L}^{-1}$, respectively. These glyphosate concentrations were average values of concentration found in wastewaters produced by rinsing herbicide containers [59]. The effects of initial $\mathrm{pH}$, hydrogen peroxide concentration, and incident irradiation were studied. The authors proposed a degradation mechanism where oxidant species are able to cleavage C-P bond to form phosphate as the first step, thus glycine is formed without AMPA and sarcosine generation. Furthermore, formaldehyde, formic acid and nitrate, ammonium, and phosphate ions were detected as final degradation products of glyphosate [59]. Other authors as Vidal et al. [61] and López et al. [62] have studied the $\mathrm{H}_{2} \mathrm{O}_{2} / \mathrm{UVC}$ system for degradation of commercial glyphosate herbicide mixture in water. Both studies compared the results obtained from a mathematical model with the experimental ones. Vidal et al. reported 80\% glyphosate remotion and 70\% TOC remotion after 12 treatment hours, these results were similar to the percentage remotion reported by López et al. [62].

About photocatalysis, the study carried out by Assalin et al. [58] showed that heterogeneous photocatalysis using $\mathrm{TiO}_{2}$ is effective to remove glyphosate and its degradation intermediaries; after 30 min of photocatalytic treatment of acid glyphosate solution $(\mathrm{pH}=10)$, TOC remotion was $92 \%$. Similarly, Chen and Liu [15] achieved $92 \%$ of glyphosate degradation after $3.5 \mathrm{~h}$ of irradiation with a starting concentration of $0.25 \mathrm{mmol} \cdot \mathrm{L}^{-1}$ and of $6.0 \mathrm{~g} \cdot \mathrm{L}^{-1}$ of $\mathrm{TiO}_{2}$ as an optimum amount of photocatalyst. Additionally, they analyzed the influence of metallic ions and other species $\left(\mathrm{H}_{2} \mathrm{O}_{2}\right.$, $\mathrm{S}_{2} \mathrm{O}_{8}{ }^{2-}, \mathrm{BrO}_{3}$ ) in photodegradation efficiency, they have reported that $0.0196 \mathrm{mmol} \cdot \mathrm{L}^{-1} \mathrm{of} \mathrm{Fe}^{3+}$ and $0.01 \mathrm{mmol} \cdot \mathrm{L}^{-1}$ of $\mathrm{Cu}^{2+}$ were optimal concentrations for the effective remotion of glyphosate from water, whereas optimum values for $\mathrm{H}_{2} \mathrm{O}_{2}, \mathrm{~S}_{2} \mathrm{O}_{8}{ }^{2-}$, and $\mathrm{BrO}_{3}$ were $0.1,1.0$, and $0.5 \mathrm{mmol} \cdot \mathrm{L}^{-1}$, respectively. Finally, in the study reported by Xue et al. [60], 76\% glyphosate degradation was achieved under the following experimental conditions: $0.1 \mathrm{mmol} \cdot \mathrm{L}^{-1}$ glyphosate concentration, $1 \mathrm{~h}$ of treatment time and synthesized cerium doped $\mathrm{TiO}_{2}$ nanotubes by hydrothermal treatment of rutile $\mathrm{TiO}_{2}$ nanoparticles followed by posterior impregnation.

Based on UV-based processes analyzed above, only one study reports the formation of degradation intermediates and final products, the rest of them only report the efficiency of glyphosate removal but not the efficiency of mineralization, so in these studies, there could be the formation of intermediate products such as AMPA, sarcosine, glycine, among others. According to Manassero et al, the concentration of wastewater from tank washing is between $50-75 \mathrm{mg} \cdot \mathrm{L}^{-1}$; other authors described in this section use a very low concentration of glyphosate. For that reason, it not easy to assume that those processes would be applicable to water treatment on a real scale where glyphosate concentrations could be greater. Furthermore, only one study reports the degradation pathway of glyphosate, showing a lack of knowledge on the degradation route by UV processes. Therefore, more studies are needed with parameters that simulate the real conditions of water in order to study the scaling of UV based treatment processes.

\subsubsection{Electrochemical Oxidation Process}

Electrochemical Oxidation (EO) is a technology that consists of supplying enough anodic energy to degrade organic matter until its total mineralization or even less complex biodegradable molecules [81]. EO of organic pollutants in water can occur through direct or indirect anodic oxidation reactions. In the first case, pollutants are oxidized by means of direct electron transference from organic pollutants toward the anode surface, which yields very poor decontamination [82]. In the second case, electrochemical oxidation of organic pollutants occurs by electrogenerated species produced by water discharge at the anode surface (M) (Reaction 12), such as physically adsorbed "active oxygen" (physisorbed hydroxyl 
radical $\left(\bullet^{\circ} \mathrm{OH}\right)$ ) or chemisorbed "active oxygen" (oxygen in the lattice of a metal oxide (MO)). The action of these oxidizing species leads to complete or partial decontamination, respectively. Comninellis et al. [81] found that the electrode material nature strongly influences both process selectivity and efficiency; in particular, several anodes favored partial and selective oxidation of pollutants (active anodes), while others favored complete combustion to $\mathrm{CO}_{2}$ (non-active anodes).

Active anodes have low oxygen overpotential, in other words, active anodes are good catalysts for oxygen evolution reaction. It is the case of $\mathrm{Pt}, \mathrm{RuO}_{2}$ or $\mathrm{IrO}_{2}$ anodes which interacts strongly with the ${ }^{\bullet} \mathrm{OH}$ radicals resulting in the transformation into higher oxide or superoxide chemisorbed at anode surface (MO) (Reaction 13). It allows only partial oxidation of organics (R) forming some organic compounds as short carboxylic acids and others degradation intermediaries, however, it depends on the complexity and stability of pollutants and treatment conditions (RO) (Reaction 14) [82].

$$
\begin{gathered}
\mathrm{M}+\mathrm{H}_{2} \mathrm{O} \rightarrow(\mathrm{M})^{\bullet} \mathrm{OH}+\mathrm{H}^{+}+\mathrm{e}^{-} \\
(\mathrm{M})^{\bullet} \mathrm{OH} \rightarrow \mathrm{MO}+\mathrm{H}^{+}+\mathrm{e}^{-} \\
\mathrm{MO}+\mathrm{R} \rightarrow \mathrm{M}+\mathrm{RO}
\end{gathered}
$$

In contrast, in non-active anodes, such as $\mathrm{PbO}_{2}, \mathrm{SnO}_{2}$ or boron-doped diamond (BDD), their surface does not provide any catalytic active site for the adsorption of organics from the aqueous medium, so non-active anodes act only as an electron sink for the removal of electrons. In these anodes, the physio-absorbed hydroxyl radicals $\left(\mathrm{M}\left({ }^{\bullet} \mathrm{OH}\right)\right)$ remain stable, which allows their availability to achieve complete pollutant's mineralization (Reaction 15) [82].

$$
(\mathrm{M})^{\bullet} \mathrm{OH}+\mathrm{R} \rightarrow \mathrm{M}+\mathrm{mCO}_{2}+\mathrm{nH}_{2} \mathrm{O}+\mathrm{H}^{+}+\mathrm{e}^{-}
$$

The process described above does not need to add oxidation catalysts to the solution and does not produce any byproducts. However, indirect electrolysis of pollutants can also occur through the mediation of some electrochemically generated redox reagents. Some of them can be present in effluents or added to the solution as an electrolyte to render the solution conductivity. These redox reagents can act as an intermediary for electrons shuttling between the electrode and the organics. These oxidation mediators can be strong oxidizing chemicals, such as active chlorine, ozone, hydrogen peroxide $\left(\mathrm{H}_{2} \mathrm{O}_{2}\right)$ and persulfate $\left(\mathrm{S}_{2} \mathrm{O}_{8}{ }^{2-}\right)$, percarbonate $\left(\mathrm{C}_{2} \mathrm{O}_{6}{ }^{2-}\right)$, and perphosphate $\left(\mathrm{P}_{2} \mathrm{O}_{8}{ }^{4-}\right)$ ions; the last ones could be present in the solution according to the following reactions [55,81].

$$
\begin{aligned}
& 2 \mathrm{SO}_{4}{ }^{2-} \rightarrow \mathrm{S}_{2} \mathrm{O}_{8}{ }^{2-}+2 \mathrm{e}^{-} \\
& 2 \mathrm{PO}_{4}{ }^{3-} \rightarrow \mathrm{P}_{2} \mathrm{O}_{8}{ }^{4-}+2 \mathrm{e}^{-} \\
& 2 \mathrm{CO}_{3}{ }^{2-} \rightarrow \mathrm{C}_{2} \mathrm{O}_{6}{ }^{2-}+2 \mathrm{e}^{-}
\end{aligned}
$$

In the case of chlorine, its natural presence or the deliberate addition of $\mathrm{Cl}^{-}$in a solution can accelerate the process of organic matter degradation. Indeed, the organic matter can be oxidized at the electrode and also in the bulk of solution by chemical reaction with the active chlorine; this reaction is substantially insensitive to electrode surface nature. On the contrary, persulfate, percarbonate and perphosphate (Reaction 16-18) are efficiently generated only using anodes with high oxygen evolution overpotential, such as boron-doped diamond (BDD) or lead dioxide $\left(\mathrm{PbO}_{2}\right)$, especially when oxygen is produced as a secondary reaction. The presence of those strong oxidants in wastewater bulk avoids mass-transfer limitation and increases process efficiency [83-86]. In summary, Figure 4 presents the electrochemical oxidation mechanism of glyphosate in an aqueous medium.

In spite of the fact that $\mathrm{EO}$ has been identified as one of the cleanest technologies to attain glyphosate removal, there are only a few reports about it. Some of them are analyzed below and summarized in Table 4. The study carried out by Neto and De Andrade [69] achieved the complete 
removal of glyphosate $\left(1000 \mathrm{mg} \cdot \mathrm{L}^{-1}\right)$ together with almost total mineralization and a $91 \%$ of phosphate production as final degradation product under the following experimental conditions: sodium chloride medium at $30 \mathrm{~mA} \cdot \mathrm{cm}^{-2}$ during $4 \mathrm{~h}$ of electrolysis on $\mathrm{RuO}_{2}$ and $\mathrm{IrO}_{2}$ dimensionally stable anode (DSA) electrodes [69]. Similarly, Lan et al. [71] studied the electrochemical oxidation process with $\mathrm{RuO}_{2} / \mathrm{TiO}_{2}$ coated titanium mesh as both anode and cathode, assisted with $\mathrm{MnO}_{2}$. They reported that glyphosate removal was significantly promoted and most of the released $\mathrm{Mn}^{2+}$ ions were oxidatively reverted to $\mathrm{MnO}_{2}$, which in turn enhanced the removal of glyphosate, allowing $80 \%$ of glyphosate degradation after $120 \mathrm{~min}$ of treatment at $10 \mathrm{~mA} \mathrm{~cm}^{-2}$ in $400 \mathrm{~mL}$ of solution with sodium sulfate as an electrolyte.

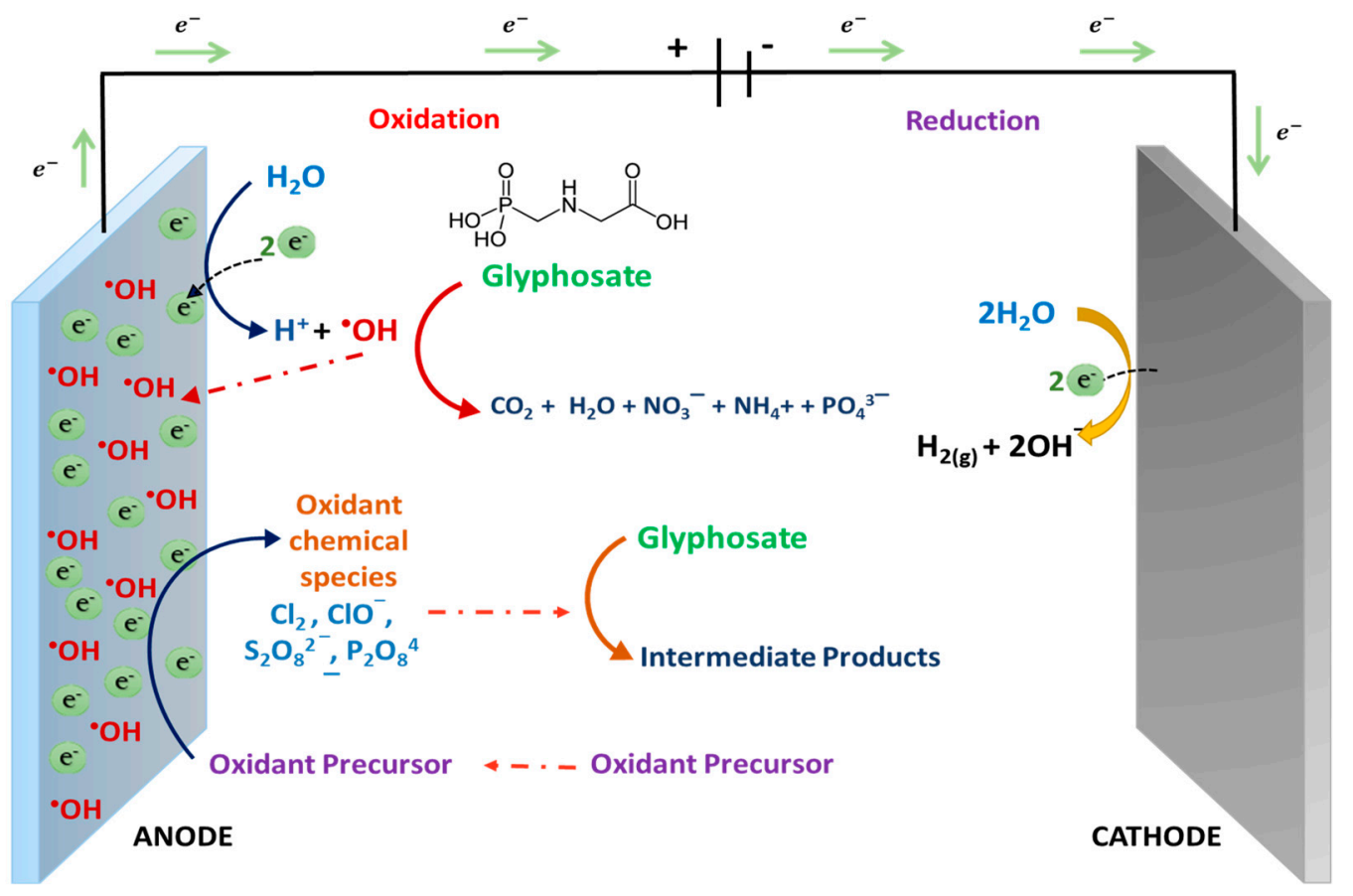

Figure 4. Oxidation mechanism of organic pollutants at non-active anodes.

Additionally, Lan et al. [71] have proposed a glyphosate degradation mechanism identifying that glycine and sarcosine were the first intermediaries that were oxidized into oxamic acid and glycolic acid, both of them were finally transformed into acetic acid and $\mathrm{NH}_{3}-\mathrm{N}$ and $\mathrm{NO}_{3}-\mathrm{N}$. In that way, the authors demonstrated that electro- $\mathrm{MnO}_{2}$ is a better process to mineralize glyphosate from water polluted than only the $\mathrm{MnO}_{2}$ oxidation process. Other authors reported the combination of adsorption over a nano-metal/resin with advanced oxidation for the degradation of a sample of industrial wastewater polluted with $258 \mathrm{mg} \cdot \mathrm{L}^{-1}$ of glyphosate. The maximum degradation rate of glyphosate was enhanced up to $60.5 \%$ using only $150 \mathrm{~mL}$ of solution in the experimental stage [70]. Recently, the study carried out by Rubí-Juárez et al. [87] proposed a conductive diamond electrochemical oxidation as an alternative to efficiently degrade glyphosate and its organic byproducts. They reported $100 \%$ TOC remotion in a solution prepared with pure herbicide, and about $90 \%$ TOC remotion in another solution prepared with industrial glyphosate. The electrolysis was carried out in a single compartment electrochemical flow cell with BDD $\left(A=78 \mathrm{~cm}^{2}\right)$ as anode and cathode supplying $100 \mathrm{~mA} / \mathrm{cm}^{2}$ of current density during $120 \mathrm{~min}$ of treatment time, in a solution with $100 \mathrm{mg} \cdot \mathrm{dm}^{-3}$ of glyphosate and sodium chlorine as support electrolyte to render the solution conductivity and generated chlorine species. Moreover, the authors reported that the achieved efficiency is due to higher concentrations of hydroxyl radicals and hypochlorite in aqueous media which allowed the formation of $\mathrm{PO}_{4}{ }^{3-}, \mathrm{NO}_{3}{ }^{-}$and $\mathrm{CO}_{2}$ as the main final products of glyphosate mineralization.

In another hand, the study carried out by Oliveira et al. [88] reported the degradation of real wastewater containing glyphosate using an electrode of $\mathrm{PbO}_{2}$ electrodeposited on a three-dimensional 
matrix of reticulated vitreous carbon (RVC) in a flow reactor. They reported that the optimized values of current density, flow rate, and temperature to lead to an improvement of $70 \%$ in the mineralization kinetics were $30 \mathrm{~mA} \cdot \mathrm{cm}^{-2}, 3000 \mathrm{~mL} \cdot \mathrm{min}^{-1}$, and $50{ }^{\circ} \mathrm{C}$, respectively. Additionally, their study reported the importance of mass transfer in anodic oxidation when a low concentration of organics is present in the effluent, so an increase in flow rate could lead to improve the mineralization kinetics, increase the global current efficiency, and decrease the specific energy consumption. Finally, it is important to mention that the study reported by Oliveira et al. [88] is one of the most complete reports because it also presents an economical estimation to treat $1 \mathrm{~m}^{3}$ of water, estimating energy consumption of 10-15 $\mathrm{kWh} \cdot \mathrm{m}^{-3}$ which corresponds to 3.0-4.5 USD $\cdot \mathrm{m}^{-3}$.

As can be noticed above, EO could be a promising technology because it lets degrade glyphosate until its total mineralization. Despite that the large-application of EO technology is under development, it has some advantages such as easy operation, environmentally friendly, easy automation, and also could be attractive from an economic point of view because they can use renewable energy from wind and solar sources. However, high cost of electrodes, possibly low conductivity of effluent, electrode fouling, corrosion phenomena, and the possible formation of intermediaries with bigger impact in water ecosystems or human health are some facts that could be considered as disadvantages of process, but also are some challenges to make effort in order to develop a better water treatment technology [73].

\subsubsection{Photoelectrocatalytic Treatment Process}

Photoelectrocatalysis (PEC) is an emerging technology that combines photocatalysis with anodic oxidation. It is based on the simultaneous application of either a constant anodic potential $\left(E_{a}\right)$ or constant electric current density (j), and light irradiation ( $h v$ ) to the photoanode [89]. The photoanode is the basis of the mechanism operation of the PEC, this constitutes a material formed by an electrode commonly used in $\mathrm{EO}$ on which a semiconductor material with photocatalytic properties is supported. It combination allows that to increase the mineralization capacity of organic pollutants in water $[74,88,89]$. In this process, the UV or visible light that radiates semiconductor material of photoanode let to occur a photocatalytic process where electron/hole pairs $\left(\mathrm{e}_{\mathrm{CB}}{ }^{-} / \mathrm{h}_{\mathrm{VB}}{ }^{+}\right)$are generated (Reaction 8, 9 and 10) [90-92]. However, in a photocatalytic process, the electron/hole pairs can be recombined; in other words, the $\mathrm{e}^{-}$in the conduction band can return to the $\mathrm{h}^{+}$in the valence band, dissipating energy in form of electromagnetic radiation or heat, it affects the formation of $\bullet \mathrm{OH}_{\text {, which }}$ are mostly responsible for the degradation of organic pollutants in aqueous medium [91-93].

To avoid recombination and consequently improved the degradation of pollutants in water, the anodic potential or constant current density applied to the photoanode continuously extracts the $\mathrm{e}^{-}$ from the $B C$ and sends them to the cathode. In this way, the recombination of $\mathrm{e}_{\mathrm{CB}}{ }^{-} / \mathrm{h}_{\mathrm{VB}}{ }^{+}$pairs is avoided and the generation of a greater amount of $\mathrm{hBV}_{\mathrm{BV}}^{+}$in the semiconductor and the subsequent generation of $\bullet \mathrm{OH}$ radicals that mineralize organic matter is encouraged. Additionally, because of the anodic potential applied to the photoanode, the electrons from the BV are easily excited and migrate to the BC, causing photocatalytic reactions can occur even with longer wavelengths (visible light instead of UV). Thus, the PEC improves photoanode efficiency and accelerates the degradation of organic compounds compared to photocatalysis and anodic oxidation when they occur independently [90-92]. Figure 5 illustrates the mechanism of the PEC process applied to remove glyphosate from water polluted.

Photoelectrocatalysis has been recently proved to remove glyphosate from water; consequently, a few studies have been reported. The first study was carried out by Rubí-Juárez et al. [74], who studied the photoelectrocatalytic process using a conductive boron-doped diamond electrode. The effect of the supporting electrolyte $\left(\mathrm{N}_{2} \mathrm{CO}_{3}, \mathrm{Na}_{2} \mathrm{SO}_{4}, \mathrm{NaCl}\right)$ and the applied current density $\left(10-100 \mathrm{~mA} \cdot \mathrm{cm}^{-2}\right)$ was studied. Results show that photoelectrocatalysis is more efficient to remove glyphosate because of the formation of higher concentrations of oxidant species formed by photoactivation ions electrogenerated by supporting electrolyte. This process reached the complete mineralization of $100 \mathrm{mg} \cdot \mathrm{L}^{-1}$ of glyphosate (Round-Up) under the following conditions: current density of $100 \mathrm{~mA} \cdot \mathrm{cm}^{-2}, \mathrm{Na}_{2} \mathrm{SO}_{4}$ as support electrolyte, $140 \mathrm{~min}$ of treatment time, and $\mathrm{Hg}$ vapor UV light lamp $(\lambda=254 \mathrm{~nm})$ with an intensity of 
$930 \mu \mathrm{W} \cdot \mathrm{cm}^{-2}$ [74]. The most recent study is from Sánchez-Montes et al. [73], who also reported that the electrochemical advanced oxidation combined with UVC light irradiation (photo-electro-chemical, P-EC) is an interesting option for water treatment. They assessed the performance of DSA and BDD anodes. The results show that after $1 \mathrm{~h}$ of treatment, a complete conversion of the glyphosate herbicide to $\mathrm{CO}_{2}$ is only attained with the DSA ${ }^{\circledR}$ electrode and low power UVC sources $(9 \mathrm{~W})$. Complete mineralization of glyphosate was also confirmed by the production of $\mathrm{NO}_{3}{ }^{-}$and $\mathrm{PO}_{4}{ }^{3-}$ ions close to the stoichiometric amounts as predicted by the theoretical equation. Additionally, energy consumption as low as $1.25 \mathrm{kWh} \cdot \mathrm{g}^{-1}$ was attained [73].

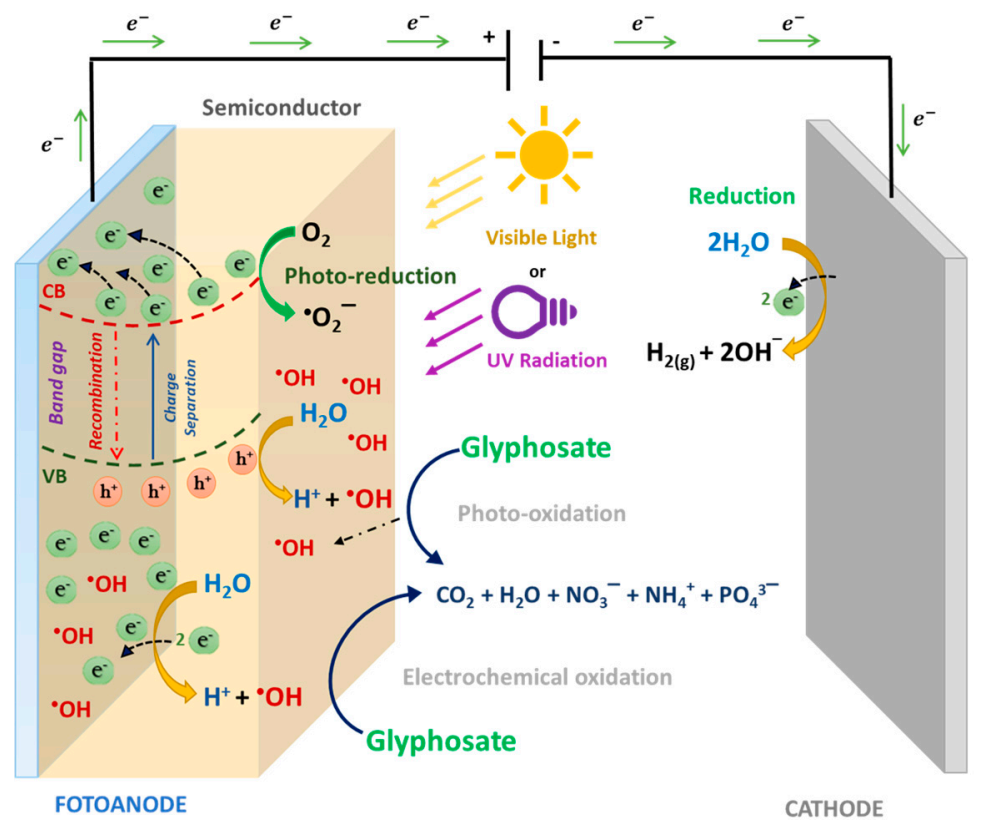

Figure 5. Schematic representation of the mechanism of photoelectrocatalysis applied to organic pollutants degradation.

As can be noticed, the few studies about photoelectrocatalysis show that it is an effective combined process to mineralize glyphosate in water. However, the studies reported at the current time do not use a photoanode or combine an electrode with photocatalyst but rather are based on radiate an electrode or solution to promote the formation of oxidant species by means of oxidation of ions in electrolytic support. Thus, there is a vast field of research to study PEC to remove organic pollutants in water specifically because PEC is a promising technology that would operate even under solar light, replacing and reducing treatment cost of operation. Finally, is important to mention that PEC is an emerging technology so there are new studies about PEC reactors and photoanode materials applied to remove other organic pollutants principally dyes or phenolic compounds [81]. All of those studies could be the start point to develop a new system to remove glyphosate from water, this will allow solving environmental problems especially in agricultural areas or zones where aerial fumigations of glyphosate persist.

\subsection{Combined Treatment Processes}

Biological (microorganisms and plants) and physicochemical processes have been combined to treat drinking water and stormwater. Some authors have studied the glyphosate removal efficiency through the adsorption process combined with microorganism degradation in biofilters systems.

Zhang et al. [93] and Yang et al. [94] have studied rain gardens or also known as biofilters or bio-retention areas. They consist of a porous soil filter media in shallows basins planted with various types of vegetation. Zhang et al. have obtained a glyphosate removal efficiency above $90 \%$ from stormwater, using a biofilter with Melaleuca ericifolia on soil (sand, $96 \%$; silt, $0.8 \%$; and clay $3.2 \%$; organic 
matter soil 0.4\%) [93], meanwhile, Yang et al. used a biofilter with plants such as Eupatorium perfoliatum, Tradescantia ohiensis, Veronicastrum virginicum, Eragrostis spectabilis, Sorghastrum nutan, Echinacea purpurea on soil (sand, topsoil, and compost) obtained a glyphosate removal efficiency of 99\% [94]. However, the role of plants within biofilters has not been defined yet, only it has been determined that glyphosate can be accumulated in aquatic macrophyte, if it does not exceed lethal concentrations [95]. Additionally, compact biofilters using organic materials (compost, bagasse) as support medium have been studied for glyphosate removal from water. Bagasse-Based biomixtures as potential substrates for biofilters or have reported that $99 \%$ of biodegraded glyphosate is attained after 6 months [25]. Vegetated buffer zones (BZ) between agricultural land and surface waters have proved to be effective filters for sediments and sediment-bound nutrients. The study carried out by Syversen and Bechman [96], achieved only $39 \%$ of glyphosate removal efficiency. The low removal efficiency of glyphosate is probably due to the adsorption of glyphosate to the smallest particle size fractions, which have lower trapping efficiency in BZ. The most recent study has studied the removal efficiency using pilot pyrrhotite constructed wetland (Pyrr-CW); in this system, the main removal mechanism is adsorption and microbial activity. In nearly one year, the natural pyrrhotite used as a substrate in a pilot constructed wetland removed $90.3 \%$ of herbicide and nutrients (total phosphorous and total nitrogen) from synthetic agriculture runoff [97].

Based on results achieved through combined systems (adsorption and microbial degradation), the authors concluded that the removal efficiencies of glyphosate by biofilters could be related to the physicochemical properties of glyphosate. Thus, through biofilters, sorption is the main removal mechanism of lipophilic compounds $\left(\mathrm{K}_{\mathrm{ow}}>4.5\right)$, whereas biodegradation is the main removal mechanism $(<20 \%)$ of hydrophilic compounds. Moreover, in the biofilter system, the feasibility of biodegradation or sorption depends on support material would fulfill and residence time.

Other authors have reported the combination of adsorption with AOPs. Zhang et al. [70] combined adsorption over nano-metal/resin with Fenton oxidation for the degradation of a sample of industrial wastewater polluted with $258 \mathrm{mg} \cdot \mathrm{L}^{-1}$ of glyphosate. They found that the maximum degradation rate of glyphosate was enhanced by up to $60 \%$ [70]. Xing et al. [98] combined catalytic wet oxidation using modified activated carbon as a catalyst in a co-current up-flow fixed bed reactor through combining AOPs and adsorption. They reported that $100 \%$ glyphosate remotion and $93 \%$ organic compounds for real wastewater polluted with $200-300 \mathrm{mg} \cdot \mathrm{L}^{-1}$ glyphosate. On the other hand, although the combination of AOPs and biological treatment has been reported as a promised method for wastewater treatment, there is no literature reported for glyphosate degradation by this combined treatment. Oller et al. [99] reported that combined AOPs-biotreatment technology has been used for the treatment of wastewater containing pesticides or herbicides, textile wastewater paper mill wastewater, olive mill wastewater, etc., to obtain effective treatment performance. This occurs because AOPs, as a pre-treatment, can convert persistent organic compounds into more biodegradable intermediates, which could subsequently be treated by biological treatment to increase performance and decrease cost. Thus, the combined processes could be an interesting technology for glyphosate treatment and can be further studied. A summary of combined treatments to remove glyphosate from water polluted are presented in Table 5.

Table 5. Removal of glyphosate from water polluted by combined treatment methods.

\begin{tabular}{ccccc}
\hline Treatment Technology & Treatment Process Associated & $\begin{array}{c}\text { Glyphosate } \\
\text { Concentration } \\
\text { (mg.a.i. } \mathbf{L}^{-\mathbf{1})}\end{array}$ & Removal (\%) & Ref. \\
\hline Vegetated buffer zones & $\begin{array}{c}\text { Adsorption in organic } \\
\text { components and clays }\end{array}$ & $0.015-0.030$ & 39 & {$[96]$} \\
\hline Biphasic rain garden & $\begin{array}{c}\text { Adsorption and microbial } \\
\text { degradation }\end{array}$ & $35-1500$ & 99 & {$[94]$} \\
\hline
\end{tabular}


Table 5. Cont.

\begin{tabular}{|c|c|c|c|c|}
\hline Treatment Technology & Treatment Process Associated & $\begin{array}{l}\text { Glyphosate } \\
\text { Concentration } \\
\left(\mathrm{mg} \cdot \mathbf{a} . \mathbf{i} \cdot \mathrm{L}^{-1}\right)\end{array}$ & Removal (\%) & Ref. \\
\hline Biofilters with plants & $\begin{array}{l}\text { Adsorption mixed with microbial } \\
\text { degradation }\end{array}$ & $0.0001-0.25$ & 90 & [93] \\
\hline Constructed wetlands & Adsorption and microbial activity & - & 90.3 & [97] \\
\hline $\begin{array}{l}\text { Adsorption and POA's } \\
\qquad\left(\mathrm{H}_{2} \mathrm{O}_{2}\right)\end{array}$ & $\begin{array}{c}\mathrm{V}=150 \mathrm{~mL} \text { of glyphosate residue } \\
\text { solution; } \mathrm{pH}=2-4 ; \text { adsorbent }= \\
\text { nano-tungsten/D201 resin }+\mathrm{H}_{2} \mathrm{O}_{2}\end{array}$ & 258.0 & 60.5 & [70] \\
\hline Adsorption with AOPs & $\begin{array}{l}\text { Catalytic wet oxidation using } \\
\text { modified activated carbon as a } \\
\text { catalyst in a co-current up flow } \\
\text { fixed bed reactor; }\end{array}$ & $200-300 \mathrm{mg} \cdot \mathrm{L}^{-1}$ & $\begin{array}{c}100.0 \\
93.0\end{array}$ & [98] \\
\hline
\end{tabular}

\section{Final Analysis and Conclusions}

Glyphosate contamination has emerged as an urgent issue and its negative effects on the environment have attracted considerable attention to develop a variety of treatment processes. The treatment technologies summarized in this review focused on the aqueous medium. Biological treatment can be applied for high amounts of wastewater, and are also low cost and eco-friendly but several operational parameters must be strictly controlled to optimize bioremediation of real water polluted with glyphosate, and in some cases, even a water pretreatment could be required. The adsorption process shows great efficiency at low glyphosate concentration, this process could be a cost-effective solution depending on the elected adsorbate and adsorption competition. However, the main disadvantage of water treatment by adsorption is the residue produced and the not-easy reuse of adsorbents. On the contrary, AOPs are effective to remove glyphosate with a shorter treatment time compared to adsorption and bioremediation. Electrochemical oxidation and photoelectrocatalysis are the cleanest processes and could be used for high glyphosate concentration in wastewater, but some aspects of electrode performance and energy consumption would limit its application. However, these are some challenges to make effort in order to develop better water treatment technology. In the same context, combined processes between AOPs and biological treatment constitute an encouraging technology for glyphosate degradation, but there is limited research. The main purpose of this combination is to increase the biodegradability of the effluent by generating smaller intermediates in the AOPs and the biological treatment would complete the degradation.

The degradation mechanism of glyphosate by different treatment processes analyzed in this review show that biological treatment for glyphosate oxidation generally follows two mechanisms related to the cleavage of C-P and C-N bonds attributed to the action of specialized enzymes in biologic organisms as bacterial and fungi species. The difference between bacterial and fungi pathways has been reported by Zhan et al. [7]. Similarly, glyphosate degradation and mineralization by AOPs are related to the cleavage of $\mathrm{C}-\mathrm{P}$ and $\mathrm{C}-\mathrm{N}$ bonds by means of hydroxyl radicals. So, glyphosate molecule is attacked by hydroxyl radicals to yield AMPA, sarcosine or some carboxylic acid to finally transform into phosphates, ammonium, and nitrate ions. However, intermediaries and final products formed during treatment time can differ based on operational conditions as treatment time, $\mathrm{pH}$ solution, glyphosate concentration, reactor design, among others.

Considering that the scope of this review is exclusively in an aqueous environment, the most applicable treatment method for glyphosate degradation could be the AOPs. These processes would be the most appropriate treatment method when glyphosate is required to eliminate from an aqueous matrix because AOPs are able to oxidize organic pollutants until its total mineralization. Some studies summarized in this work have reported good degradation efficiencies, it is the case of the work reported by Rubí-Juárez et al. [74], where $100 \%$ of glyphosate was mineralized by advanced oxidation in the presence of light using BDD anodes. However, AOPs are known to be an emerging technology in the 
remediation of soils and air polluted with different organic pollutants; glyphosate degradation in soils polluted has not been studied yet. The work reported by Cheng et al. [100] provides a general overview of AOPs to pesticides, polycyclic aromatic hydrocarbons (PAHs), polychlorinated biphenyls (PCBs) and total petroleum hydrocarbons (TPHs) contaminated soils remediation, and the work reported by Nevárez-Martínez et al. [101] provides the efficiency of anodic oxidation to remove organic pollutants in air. Thus, AOPs could be applied in the remediation of glyphosate in any matrix.

Finally, there has been some research assessing the degradation of this important herbicide through the different treatment processes. However, the majority of this research has been developed at a laboratory scale using controlled conditions and some of them have employed glyphosate analytic standard, not a commercial herbicide. Therefore, it is necessary to study the applicability of this process in the treatment of real wastewater. Additionally, further research is still necessary in order to know more precise mechanisms during the glyphosate oxidation process and the toxicity of intermediates subproducts. Additionally, an analysis of energetic consumption and operation costs at a real scale is still necessary in order to develop a water treatment technology that allows solving environmental problems, especially in agricultural areas or zones where aerial fumigations of glyphosate persist.

Author Contributions: Conceptualization, all authors; methodology, P.J.E.-M., C.V.-V., P.A.-P., L.F. and J.L.P.; investigation, P.J.E.-M., C.V.-V., P.A.-P., L.F. and J.L.P.; writing-original draft preparation, P.J.E.-M., C.V.-V. and P.A.-P.; writing - review and editing, C.V.-V. and P.A.-P.; supervision P.J.E.-M.; project administration, P.J.E.-M. All authors have read and agreed to the published version of the manuscript.

Funding: This project was funding through the project "Study of the Degradation of Glyphosate in Aqueous Medium by Photoelectrocatalysis Using a Boron Doped Diamond Electrode Modified with Titanium Dioxide as Photoanode", Code: QINV0105-IINV529020200.

Acknowledgments: The authors thank the Research Directorate of the Pontificia Universidad Católica del Ecuador for funding through the project "Study of the Degradation of Glyphosate in Aqueous Medium by Photoelectrocatalysis Using a Boron Doped Diamond Electrode Modified with Titanium Dioxide as Photoanode", Code: QINV0105-IINV529020200.

Conflicts of Interest: The authors declare no conflict of interest.

\begin{tabular}{ll} 
Abbreviations \\
$\bullet$ OH & Hydroxyl Radical \\
ACF & Activated Carbon Fiber \\
AMPA & Aminomethylphosphonic Acid \\
AOPs & Advanced Oxidation Processes \\
BDD & Boron-Doped Diamond \\
BZ & Buffer Zones \\
C-N & Carbon-nitrogen bond \\
COD & Chemical Organic Demand \\
C-P & Carbon-phosphorus bond \\
DSA & Dimensionally Stable Anode \\
$\mathrm{E}_{\mathrm{a}}$ & Anodic Potential \\
$\mathrm{e}_{\mathrm{CB}}{ }^{-} / \mathrm{h}_{\mathrm{VB}}{ }^{+}$ & Electron/hole pairs \\
EO & Electrochemical Oxidation \\
EPSP & 5-enolpiruvil-shikimato-3-phosphate-synthetase enzyme \\
FAO & Food and Agriculture Organization \\
GLY & Glyphosate \\
GO/TiO & Graphene Oxide and Titanium Dioxide \\
IARC & International Agency for Research on Cancer \\
IBT & Immobilizing Bacterial Technology \\
$\mathrm{K}_{\mathrm{OW}}$ & Octanol-water partition coefficient \\
$\mathrm{MO}$ & Metal Oxide \\
$\mathrm{NHE}$ & Normal Hydrogen Electrode \\
PEC & Photoelectrocatalysis \\
PSf & Polysulfone \\
\hline
\end{tabular}




$\begin{array}{ll}\text { TMP } & \text { Trans-Membrane Pressure } \\ \text { TOC } & \text { Total Organic Carbon } \\ \text { UV } & \text { Ultraviolet light } \\ \text { WHO } & \text { World Health Organization }\end{array}$

\section{References}

1. Benbrook, C.M. Trends in glyphosate herbicide use in the United States and globally. Environ. Sci. Eur. 2016, 28, 1-15. [CrossRef] [PubMed]

2. Wen-Tien, T. Trends in the Use of Glyphosate Herbicide and Its Relevant Regulations in Taiwan: A Water Contaminant of Increasing Concern. Toxics 2019, 7, 4.

3. Nicolopoulou-Stamati, P.; Maipas, S.; Kotampasi, C.; Stamatis, P.; Hens, L. Chemical Pesticides and Human Health: The Urgent Need for a New Concept in Agriculture. Front. Public Health 2016, 4, 148. [CrossRef] [PubMed]

4. Villamar-Ayala, C.A.; Carrera-Cevallos, J.V.; Vasquez-Medrano, R.; Espinoza-Montero, P.J. Fate, eco-toxicological characteristics, and treatment processes applied to water polluted with glyphosate: A critical review. Crit. Rev. Environ. Sci. Technol. 2019, 49, 1476-1514. [CrossRef]

5. Giesy, J.P.; Dobson, S.; Solomon, K.R. Ecotoxicological risk assessment for Roundup ${ }^{\circledR}$ herbicide. Rev. Environ. Contam. Toxicol. 2000, 167, 35-120.

6. Annett, R.; Habibi, H.R.; Hontela, A. Impact of glyphosate and glyphosate-based herbicides on the freshwater environment. J. Appl. Toxicol. 2014, 34, 458-479. [CrossRef]

7. Zhan, H.; Feng, Y.; Fan, X.; Chen, S. Recent advances in glyphosate biodegradation. Appl. Microbiol. Biotechnol. 2018, 102, 5033-5043. [CrossRef]

8. Salazar-López, N.J.; Madrid, M.L.A. Herbicida Glifosato: Usos, Toxicidad Y Regulación. Rev. Ciencias Biol. T Salud Univ. Sonora 2011, 11, 23-28. [CrossRef]

9. Coupe, R.H.; Kalkhoff, S.J.; Capel, P.D.; Gregoire, C. Fate and transport of glyphosate and aminomethylphosphonic acid in surface waters of agricultural basins. Pest Manag. Sci. 2012, 68, 16-30. [CrossRef] [PubMed]

10. Grunewald, K.; Schmidt, W.; Unger, C.; Hanschmann, G. Behavior of glyphosate and aminomethylphosphonic acid (AMPA) in soils and water of reservoir Radeburg II catchment (Saxony/Germany). J. Plant Nutr. Soil Sci. 2001, 164, 65-70. [CrossRef]

11. Székács, A.; Darvas, B. Forty years with glyphosate. In Herbicides-Properties, Synthesis and Control of Weeds; Nagib, M., Ed.; InTech: London, UK, 2012; pp. 247-284.

12. de Brito Rodrigues, L.; Gonçalves Costa, G.; Lundgren Thá, E.; da Silva, L.R.; de Oliveira, R.; Morais Leme, D.; Cestari, M.M.; Koppe Grisolia, C.; Campos Valadares, M.; de Oliveira, G.A.R. Impact of the glyphosate-based commercial herbicide, its components and its metabolite AMPA on non-target aquatic organisms. Mutat. Res. Genet. Toxicol. Environ. Mutagen. 2019, 842, 94-101. [CrossRef] [PubMed]

13. Van Bruggen, A.H.C.; He, M.M.; Shin, K.; Mai, V.; Jeong, K.C.; Finckh, M.R.; Morris, J.G. Environmental and health effects of the herbicide glyphosate. Sci. Total Environ. 2018, 616-617, 255-268. [CrossRef] [PubMed]

14. Bai, S.H.; Ogbourne, S.M. Glyphosate: Environmental contamination, toxicity and potential risks to human health via food contamination. Environ. Sci. Pollut. Res. 2016, 23, 18988-19001. [CrossRef] [PubMed]

15. Chen, S.; Liu, Y. Study on the photocatalytic degradation of glyphosate by $\mathrm{TiO}_{2}$ photocatalyst. Chemosphere 2007, 67, 1010-1017. [CrossRef] [PubMed]

16. Li, Y.; Zhao, C.; Wen, Y.; Wang, Y.; Yang, Y. Adsorption performance and mechanism of magnetic reduced graphene oxide in glyphosate contaminated water. Environ. Sci. Pollut. Res. 2018, 25, 21036-21048. [CrossRef] [PubMed]

17. Sviridov, A.V.; Shushkova, T.V.; Ermakova, I.T.; Ivanova, E.V.; Epiktetov, D.O.; Leontievskya, A.A. Microbial Degradation of Glyphosate Herbicides (Review). Appl. Biochem. Microbiol. 2015, 51, 188-195. [CrossRef]

18. Fan, J.; Yang, G.; Zhao, H.; Shi, G.; Geng, Y.; Hou, T.; Tao, K. Isolation, identification and characterization of a glyphosate-degrading bacterium, Bacillus cereus CB4, from soil. J. Gen. Appl. Microbiol. 2012, 58, $263-271$. [CrossRef]

19. Wijekoon, N.; Yapa, N. Assessment of plant growth promoting rhizobacteria (PGPR) on potential biodegradation of glyphosate in contaminated soil and aquifers. Groundw. Sustain. Dev. 2018, 7, 465-469. [CrossRef] 
20. Fu, G.M.; Chen, Y.; Li, R.Y.; Yuan, X.Q.; Liu, C.M.; Li, B.; Wan, Y. Pathway and rate-limiting step of glyphosate degradation by Aspergillus oryzae A-F02. Prep. Biochem. Biotechnol. 2017, 47, 782-788. [CrossRef]

21. Adelowo, F.E.; Olu-Arotiowa, O.A.; Amuda, O.S. Biodegradation of Glyphosate by Fungi Species Phosphorus (C-P) bond. Adv. Biosci. Bioeng. 2014, 2, 104-118.

22. Balthazor, T.M.; Hallas, L.E. Glyphosate-degrading microorganisms from industrial activated sludge. Appl. Environ. Microbiol. 1986, 51, 432-434. [CrossRef] [PubMed]

23. McAuliffe, K.S.; Hallas, L.E.; Kulpa, C.F. Glyphosate degradation by Agrobacterium radiobacter isolated from activated sludge. J. Ind. Microbiol. 1990, 6, 219-221. [CrossRef]

24. Heitkamp, M.A.; Adams, W.J.; Hallas, L.E. Glyphosate degradation by immobilized bacteria: Laboratory studies showing feasibility for glyphosate removal from waste water. Can. J. Microbiol. 1992, 38, 921-928. [CrossRef]

25. Roffignac, L.; Cattan, P.; Mailloux, J.; Herzog, D.; Le Bellec, F. Efficiency of a bagasse substrate in a biological bed system for the degradation of glyphosate, malathion and lambda-cyhalothrin under tropical climate conditions. Pest Manag. Sci. 2008, 64, 1303-1313. [CrossRef]

26. Mercurio, P.; Flores, F.; Mueller, J.F.; Carter, S.; Negri, A.P. Glyphosate persistence in seawater. Mar. Pollut. Bull. 2014, 85, 385-390. [CrossRef] [PubMed]

27. Tazdaït, D.; Salah, R.; Grib, H.; Abdi, N.; Mameri, N. Kinetic study on biodegradation of glyphosate with unacclimated activated sludge. Int. J. Environ. Health Res. 2018, 28, 448-459. [CrossRef] [PubMed]

28. Singh, S.; Kumar, V.; Singh, J. Kinetic study of the biodegradation of glyphosate by indigenous soil bacterial isolates in presence of humic acid, Fe(III) and Cu(II) ions. J. Environ. Chem. Eng. 2019, 7, 103098. [CrossRef]

29. Castro, J.V.; Peralba, M.C.R.; Ayub, M.A.Z. Biodegradation of the herbicide glyphosate by filamentous fungi in platform shaker and batch bioreactor. J. Environ. Sci. Health Part B Pestic. Food Contam. Agric. Wastes 2007, 42, 883-886. [CrossRef]

30. Bouchiat, R.; Veignie, E.; Grizard, D.; Soebert, C.; Vigier, M.; Rafin, C. Ability of filamentous fungi to degrade four emergent water priority pollutants. Desalin. Water Treat. 2016, 57, 6740-6746. [CrossRef]

31. Obojska, A.; Ternan, N.G.; Lejczak, B.; Kafarski, P.; McMullan, G. Organophosphonate Utilization by the Thermophile Geobacillus caldoxylosilyticus T20. Appl. Environ. Microbiol. 2002, 68, 2081-2084. [CrossRef]

32. Carles, L.; Gardon, H.; Joseph, L.; Sanchís, J.; Farré, M.; Artigas, J. Meta-analysis of glyphosate contamination in surface waters and dissipation by biofilms. Environ. Int. 2019, 124, 284-293. [CrossRef] [PubMed]

33. Hu, Y.S.; Zhao, Y.Q.; Sorohan, B. Removal of glyphosate from aqueous environment by adsorption using water industrial residual. Desalination 2011, 271, 150-156. [CrossRef]

34. Yang, Q.; Wang, J.; Zhang, W.; Liu, F.; Yue, X.; Liu, Y.; Yang, M.; Li, Z.; Wang, J. Interface engineering of metal organic framework on graphene oxide with enhanced adsorption capacity for organophosphorus pesticide. Chem. Eng. J. 2017, 313, 19-26. [CrossRef]

35. Wang, Y.; Ren, B.; Zhao, Y.; English, A.; Cannon, M. A comparison of alum sludge with peat for aqueous glyphosate removal for maximizing their value for practical use. Water Sci. Technol. 2018, 2017, 450-456. [CrossRef] [PubMed]

36. Zavareh, S.; Farrokhzad, Z.; Darvishi, F. Modification of zeolite 4A for use as an adsorbent for glyphosate and as an antibacterial agent for water. Ecotoxicol. Environ. Saf. 2018, 155, 1-8. [CrossRef] [PubMed]

37. Santos, T.R.T.; Andrade, M.B.; Silva, M.F.; Bergamasco, R.; Hamoudi, S. Development of $\alpha$ - and $\gamma$-Fe $\mathrm{F}_{2} \mathrm{O}_{3}$ decorated graphene oxides for glyphosate removal from water. Environ. Technol. 2019, 40, 1118-1137. [CrossRef]

38. Dissanayake Herath, G.A.; Poh, L.S.; Ng, W.J. Statistical optimization of glyphosate adsorption by biochar and activated carbon with response surface methodology. Chemosphere 2019, 227, 533-540. [CrossRef]

39. Jia, D.; Liu, M.; Xia, J.; Li, C. Effective removal of aqueous glyphosate using $\mathrm{CuFe}_{2} \mathrm{O}_{4} @$ biochar derived from phragmites. J. Chem. Technol. Biotechnol. 2020, 95, 196-204. [CrossRef]

40. Xiao, G.; Meng, Q. D151 resin preloaded with $\mathrm{Fe}^{3+}$ as a salt resistant adsorbent for glyphosate from water in the presence 16\% NaCl. Ecotoxicol. Environ. Saf. 2020, 190, 110140. [CrossRef]

41. Ren, Z.; Dong, Y.; Liu, Y. Enhanced glyphosate removal by montmorillonite in the presence of Fe(III). Ind. Eng. Chem. Res. 2014, 53, 14485-14492. [CrossRef]

42. Guo, F.; Zhou, M.; Xu, J.; Fein, J.B.; Yu, Q.; Wang, Y.; Huang, Q.; Rong, X. Glyphosate adsorption onto kaolinite and kaolinite-humic acid composites: Experimental and molecular dynamics studies. Chemosphere 2020, 263, 127979. [CrossRef] [PubMed] 
43. Khoury, G.A.; Gehris, T.C.; Tribe, L.; Torres Sánchez, R.M.; dos Santos Afonso, M. Glyphosate adsorption on montmorillonite: An experimental and theoretical study of surface complexes. Appl. Clay Sci. 2010, 50, 167-175. [CrossRef]

44. Pankajakshan, A.; Sinha, M.; Ojha, A.A.; Mandal, S. Water-Stable Nanoscale Zirconium-Based Metal-Organic Frameworks for the Effective Removal of Glyphosate from Aqueous Media. ACS Omega 2018, 3, 7832-7839. [CrossRef]

45. Liu, Z.Y.; Xie, M.; Ni, F.; Xu, Y.H. Nanofiltration process of glyphosate simulated wastewater. Water Sci. Technol. 2012, 65, 816-822. [CrossRef] [PubMed]

46. Yuan, J.; Duan, J.; Saint, C.P.; Mulcahy, D. Removal of glyphosate and aminomethylphosphonic acid from synthetic water by nanofiltration. Environ. Technol. 2018, 39, 1384-1392. [CrossRef] [PubMed]

47. Saitúa, H.; Giannini, F.; Padilla, A.P. Drinking water obtaining by nanofiltration from waters contaminated with glyphosate formulations: Process evaluation by means of toxicity tests and studies on operating parameters. J. Hazard. Mater. 2012, 227, 204-210. [CrossRef] [PubMed]

48. Hosseini, N.; Toosi, M.R. Removal of 2,4-D, glyphosate, trifluralin, and butachlor herbicides from water by polysulfone membranes mixed by graphene oxide/ $\mathrm{TiO}_{2}$ nanocomposite: Study of filtration and batch adsorption. J. Environ. Health Sci. Eng. 2019, 17, 247-258. [CrossRef]

49. Herath, I.; Kumarathilaka, P.; Al-Wabel, M.I.; Abduljabbar, A.; Ahmad, M.; Usman, A.R.A.; Vithanage, M. Mechanistic modeling of glyphosate interaction with rice husk derived engineered biochar. Microporous Mesoporous Mater. 2016, 225, 280-288. [CrossRef]

50. Jönsson, J.; Camm, R.; Hall, T. Removal and degradation of Glyphosate in water treatment: A review. J. Water Supply Res. Technol. AQUA 2013, 62, 395-408. [CrossRef]

51. Speth, T.F. Glyphosate Removal from Drinking Water. J. Environ. Eng. 1993, 119, 1139-1157. [CrossRef]

52. Sheals, J.; Sjöberg, S.; Persson, P. Adsorption of Glyphosate on Goethite: Molecular Characterization of Surface Complexes. Environ. Sci. Technol. 2002, 36, 3090-3095. [CrossRef] [PubMed]

53. Chen, J.P.; Mou, H.; Wang, L.K.; Matsuura, T. Membrane filtration. In Advanced Physicochemical Treatment Processes; Wang, L.K., Hung, Y.-T., Shammas, N., Eds.; Humana Press: Totowa, NJ, USA, 2007; Volume 4, pp. 213-279.

54. Andreozzi, R. Advanced oxidation processes (AOP) for water purification and recovery. Catal. Today 1999, 53, 51-59. [CrossRef]

55. Wang, J.L.; Xu, L.J. Advanced oxidation processes for wastewater treatment: Formation of hydroxyl radical and application. Crit. Rev. Environ. Sci. Technol. 2012, 8, 251-325. [CrossRef]

56. Sirés, I.; Brillas, E.; Oturan, M.A.; Rodrigo, M.A.; Panizza, M. Electrochemical advanced oxidation processes: Today and tomorrow. A review. Environ. Sci. Pollut. Res. 2014, 21, 8336-8367. [CrossRef] [PubMed]

57. Chen, Y.; Wu, F.; Lin, Y.; Deng, N.; Bazhin, N.; Glebov, E. Photodegradation of glyphosate in the ferrioxalate system. J. Hazard. Mater. 2007, 148, 360-365. [CrossRef] [PubMed]

58. Assalin, M.R.; de Moraes, S.G.; Queiroz, S.C.N.; Ferracini, V.L.; Duran, N. Studies on degradation of glyphosate by several oxidative chemical processes: Ozonation, photolysis and heterogeneous photocatalysis. J. Environ. Sci. Health Part B Pestic. Food Contam. Agric. Wastes 2009, 45, 89-94. [CrossRef] [PubMed]

59. Manassero, A.; Passalia, C.; Negro, A.C.; Cassano, A.E.; Zalazar, C.S. Glyphosate degradation in water employing the $\mathrm{H}_{2} \mathrm{O}_{2} / \mathrm{UVC}$ process. Water Res. 2010, 44, 3875-3882. [CrossRef]

60. Xue, W.; Zhang, G.; Xu, X.; Yang, X.; Liu, C.; Xu, Y. Preparation of titania nanotubes doped with cerium and their photocatalytic activity for glyphosate. Chem. Eng. J. 2011, 167, 397-402. [CrossRef]

61. Vidal, E.; Negro, A.; Cassano, A.; Zalazar, C. Simplified reaction kinetics, models and experiments for glyphosate degradation in water by the UV/H2O2 process. Photochem. Photobiol. Sci. 2015, 14, 366-377. [CrossRef]

62. López, A.; Coll, A.; Lescano, M.; Zalazar, C. Advanced oxidation of commercial herbicides mixture: Experimental design and phytotoxicity evaluation. Environ. Sci. Pollut. Res. 2018, 25, 21393-21402. [CrossRef]

63. Yang, Y.; Deng, Q.; Yan, W.; Jing, C.; Zhang, Y. Comparative study of glyphosate removal on goethite and magnetite: Adsorption and photo-degradation. Chem. Eng. J. 2018, 352, 581-589. [CrossRef]

64. Garcia-Muñoz, P.; Dachtler, W.; Altmayer, B.; Schulz, R.; Robert, D.; Seitz, F.; Rosenfeldt, R.; Keller, N. Reaction pathways, kinetics and toxicity assessment during the photocatalytic degradation of glyphosate and myclobutanil pesticides: Influence of the aqueous matrix. Chem. Eng. J. 2020, 384, 123315. [CrossRef] 
65. Lv, Y.-R.; He, R.-K.; Chen, Z.-Y.; Li, X.; Xu, Y.-H. Fabrication of hierarchical copper sulfide/bismuth tungstate p-n heterojunction with two-dimensional (2D) interfacial coupling for enhanced visible-light photocatalytic degradation of glyphosate. J. Colloid Interface Sci. 2020, 560, 293-302. [CrossRef] [PubMed]

66. Souza, D.R.D.; Trovõ, A.G.; Filho, N.R.A.; Silva, M.A.A.; Machado, A.E.H. Degradation of the commercial herbicide glyphosate by photo-fenton process: Evaluation of kinetic parameters and toxicity. J. Braz. Chem. Soc. 2013, 24, 1451-1460. [CrossRef]

67. Balci, B.; Oturan, M.A.; Oturan, N.; Sires, I. Decontamination of aqueous glyphosate, (aminomethyl) phosphonic acid, and glufosinate solutions by electro-fenton-iike process with $\mathrm{Mn}^{2+}$ as the catalyst. J. Agric. Food Chem. 2009, 57, 4888-4894. [CrossRef]

68. Lan, H.; He, W.; Wang, A.; Liu, R.; Liu, H.; Qu, J.; Huang, C.P. An activated carbon fiber cathode for the degradation of glyphosate in aqueous solutions by the Electro-Fenton mode: Optimal operational conditions and the deposition of iron on cathode on electrode reusability. Water Res. 2016, 105, 575-582. [CrossRef]

69. Aquino Neto, S.; de Andrade, A.R. Electrooxidation of glyphosate herbicide at different DSA®compositions: $\mathrm{pH}$, concentration and supporting electrolyte effect. Electrochim. Acta 2009, 54, 2039-2045. [CrossRef]

70. Zhang, M.D.; Wei, Y.F.; Zhao, K.; Mei, R.W.; Huang, M. Glyphosate Degradation with Industrial Wastewater Effluent by Combined Adsorption Treatment and Advanced Oxidation Processes. Adv. Mater. Res. 2011, 233-235, 369-372. [CrossRef]

71. Lan, H.; Jiao, Z.; Zhao, X.; He, W.; Wang, A.; Liu, H.; Liu, R.; Qu, J. Removal of glyphosate from water by electrochemically assisted $\mathrm{MnO}_{2}$ oxidation process. Sep. Purif. Technol. 2013, 117, 30-40. [CrossRef]

72. Tran, M.H.; Nguyen, H.C.; Le, T.S.; Dang, V.A.D.; Cao, T.H.; Le, C.K.; Dang, T.-D. Degradation of glyphosate herbicide by an electro-Fenton process using carbon felt cathode. Environ. Technol. 2019, 1-10. [CrossRef]

73. Sánchez-Montes, I.; Pérez, J.F.; Sáez, C.; Rodrigo, M.A.; Cañizares, P.; Aquino, J.M. Assessing the performance of electrochemical oxidation using DSA®and BDD anodes in the presence of UVC light. Chemosphere 2020, 238, 124575. [CrossRef] [PubMed]

74. Rubí-Juárez, H.; Cotillas, S.; Sáez, C.; Cañizares, P.; Barrera-Díaz, C.; Rodrigo, M.A. Use of conductive diamond photo-electrochemical oxidation for the removal of pesticide glyphosate. Sep. Purif. Technol. 2016, 167, 127-135. [CrossRef]

75. Deng, Y.; Zhao, R. Advanced Oxidation Processes (AOPs) in Wastewater Treatment. Curr. Pollut. Rep. 2015, 1, 167-176. [CrossRef]

76. Serra-Clusellas, A.; De Angelis, L.; Beltramo, M.; Bava, M.; De Frankenberg, J.; Vigliarolo, J.; Di Giovanni, N.; Stripeikis, J.D.; Rengifo-Herrera, J.A.; Fidalgo De Cortalezzi, M.M. Glyphosate and AMPA removal from water by solar induced processes using low Fe(III) or Fe(II) concentrations. Environ. Sci. Water Res. Technol. 2019, 5, 1932-1942. [CrossRef]

77. Tran, N.; Drogui, P.; Doan, T.L.; Le, T.S.; Nguyen, H.C. Electrochemical degradation and mineralization of glyphosate herbicide. Environ. Technol. 2017, 38, 2939-2948. [CrossRef]

78. Azrague, K.; Bonnefille, E.; Pradines, V.; Pimienta, V.; Oliveros, E.; Maurette, M.T.; Benoit-Marquié, F. Hydrogen peroxide evolution during V-UV photolysis of water. Photochem. Photobiol. Sci. 2005, 4, 406-408. [CrossRef]

79. Nevárez-Martínez, M.C.; Espinoza-Montero, P.J.; Quiroz-Chávez, F.J.; Ohtani, B. Fotocatálisis: Inicio, Actualidad y Perspectivas a Través del $\mathrm{TiO}_{2}$. Avances en Química. 2017, 12, 45-49.

80. Byrne, C.; Subramanian, G.; Pillai, S.C. Recent advances in photocatalysis for environmental applications. J. Environ. Chem. Eng. 2018, 6, 3531-3555. [CrossRef]

81. Comninellis, C.; Chen, G. Electrochemistry for the Environment; Springer: New York, NY, USA, 2010; ISBN 9780387369228.

82. De Battisti, A.; Martínez-Huitle, C.A. Electrochemical Waster and Wastewater Treatment; Butterworth-Heinemann: Oxford, UK, 2018.

83. Espinoza-Montero, P.J.; Vasquez-Medrano, R.; Ibanez, J.G.; Frontana-Uribe, B.A. Efficient Anodic Degradation of Phenol Paired to Improved Cathodic Production of $\mathrm{H}_{2} \mathrm{O}_{2}$ at BDD Electrodes. J. Electrochem. Soc. 2013, 160, G3171-G3177. [CrossRef]

84. Bravo-Yumi, N.P.; Espinoza-Montero, P.; Brillas, E.; Peralta-Hernández, J.M. Electrochemical abatement of atrazine solutions using an undivided stirred tank cell with pt or BDD anode. J. Mex. Chem. Soc. 2018, 62, 295-304. 
85. Ochoa-Chavez, A.S.; Pieczyńska, A.; Fiszka Borzyszkowska, A.; Espinoza-Montero, P.J.; Siedlecka, E.M. Electrochemical degradation of 5-FU using a flow reactor with BDD electrode: Comparison of two electrochemical systems. Chemosphere 2018, 201, 816-825. [CrossRef] [PubMed]

86. Armijos-Alcocer, K.G.; Espinoza-Montero, P.J.; Frontana-Uribe, B.A.; Barrera-Diaz, C.E.; Nevárez-Martínez, M.C.; Fierro-Naranjo, G.C. Electrochemical Degradation of Nonylphenol Ethoxylate-7 (NP7EO) Using a DiaCleanßCell Equipped with Boron-Doped Diamond Electrodes (BDD). Water Air Soil Pollut. 2017, 228, 289. [CrossRef]

87. Rubí-Juárez, H.; Cotillas, S.; Sáez, C.; Cañizares, P.; Barrera-Díaz, C.; Rodrigo, M.A. Removal of herbicide glyphosate by conductive-diamond electrochemical oxidation. Appl. Catal. B Environ. 2016, 188, 305-312. [CrossRef]

88. Oliveira, K.S.G.C.; Farinos, R.M.; Veroli, A.B.; Ruotolo, L.A.M. Electrochemical incineration of glyphosate wastewater using three-dimensional electrode. Environ. Technol. 2019. [CrossRef]

89. Rajeshwar, K. Photoelectrochemistry and the environment. J. Appl. Electrochem. 1995, 25, 1067-1082. [CrossRef]

90. Bessegato, G.G.; Guaraldo, T.T.; de Brito, J.F.; Brugnera, M.; Zanoni, M. Achievements and Trends in Photoelectrocatalysis: From Environmental to Energy Applications. J. Photochem. Photobiol. A Chem. 2015, 6, 415-441. [CrossRef]

91. Garcia-segura, S.; Brillas, E. Applied photoelectrocatalysis on the degradation of organic pollutants in wastewaters. J. Photochem. Photobiol. C Photochem. Rev. 2017, 31, 1-35. [CrossRef]

92. Daghrir, R.; Drogui, P.; Robert, D. Photoelectrocatalytic technologies for environmental applications. J. Photochem. Photobiol. A Chem. 2012, 238, 41-52. [CrossRef]

93. Zhang, K.; Deletic, A.; Page, D.; McCarthy, D.T. Surrogates for herbicide removal in stormwater biofilters. Water Res. 2015, 81, 64-71. [CrossRef]

94. Yang, H.; Dick, W.A.; McCoy, E.L.; Phelan, P.L.; Grewal, P.S. Field evaluation of a new biphasic rain garden for stormwater flow management and pollutant removal. Ecol. Eng. 2013, 54, 22-31. [CrossRef]

95. Pérez, D.J.; Okada, E.; Menone, M.L.; Costa, J.L. Can an aquatic macrophyte bioaccumulate glyphosate? Development of a new method of glyphosate extraction in Ludwigia peploides and watershed scale validation. Chemosphere 2017, 185, 975-982. [CrossRef] [PubMed]

96. Syversen, N.; Bechmann, M. Vegetative buffer zones as pesticide filters for simulated surface runoff. Ecol. Eng. 2004, 22, 175-184. [CrossRef]

97. Liang, Y.; Wei, D.; Hu, J.; Zhang, J.; Liu, Z.; Li, A.; Li, R. Glyphosate and nutrients removal from simulated agricultural runoff in a pilot pyrrhotite constructed wetland. Water Res. 2019, 168, 115154. [CrossRef] [PubMed]

98. Xing, B.; Chen, H.; Zhang, X. Efficient degradation of organic phosphorus in glyphosate wastewater by catalytic wet oxidation using modified activated carbon as a catalyst. Environ. Technol. 2018, 39, 749-758. [CrossRef] [PubMed]

99. Oller, I.; Malato, S.; Sánchez-Pérez, J.A. Combination of Advanced Oxidation Processes and biological treatments for wastewater decontamination-A review. Sci. Total Environ. 2011, 409, 4141-4166. [CrossRef]

100. Cheng, M.; Zeng, G.; Huang, D.; Lai, C.; Xu, P.; Zhang, C.; Liu, Y. Hydroxyl radicals based advanced oxidation processes (AOPs) for remediation of soils contaminated with organic compounds: A review. Chem. Eng. J. 2016, 284, 582-598. [CrossRef]

101. Nevárez-Martínez, M.C.; Kobylanski, M.P.; Mazierski, P.; Wółkiewicz, J.; Trykowski, G.; Malankowska, A.; Kozak, M.; Espinoza-Montero, P.J.; Zaleska-Medynska, A. Self-Organized $\mathrm{TiO}_{2}-\mathrm{MnO}_{2}$ nanotube arrays for efficient photocatalytic degradation of toluene. Molecules 2017, 22, 564. [CrossRef]

Sample Availability: Samples of the compounds are not available from the authors.

Publisher's Note: MDPI stays neutral with regard to jurisdictional claims in published maps and institutional affiliations.

(C) 2020 by the authors. Licensee MDPI, Basel, Switzerland. This article is an open access article distributed under the terms and conditions of the Creative Commons Attribution (CC BY) license (http://creativecommons.org/licenses/by/4.0/). 